\title{
Influence of cycling profile, depth of discharge and temperature on commercial LFP/C cell ageing: post-mortem material analysis of structure, morphology and chemical composition
}

\author{
M. Simolka ${ }^{1}$ D . J. -F. Heger ${ }^{1} \cdot$ H. Kaess ${ }^{1} \cdot$ I. Biswas $^{2} \cdot$ K. A. Friedrich ${ }^{2,3}$ (D)
}

Received: 28 April 2020 / Accepted: 17 August 2020 / Published online: 27 September 2020

(c) The Author(s) 2020

\begin{abstract}
The paper presents post-mortem analysis of commercial $\mathrm{LiFePO}_{4}$ battery cells, which are aged at $55^{\circ} \mathrm{C}$ and $-20{ }^{\circ} \mathrm{C}$ using dynamic current profiles and different depth of discharges (DOD). Post-mortem analysis focuses on the structure of the electrodes using atomic force microscopy (AFM) and scanning electron microscopy (SEM) and the chemical composition changes using energy dispersive X-ray spectroscopy (SEM-EDX) and X-ray photoelectron spectroscopy (XPS). The results show that ageing at lower DOD results in higher capacity fading compared to higher DOD cycling. The anode surface aged at $55^{\circ} \mathrm{C}$ forms a dense cover on the graphite flakes, while at the anode surface aged at $-20^{\circ} \mathrm{C}$ lithium plating and LiF crystals are observed. As expected, Fe dissolution from the cathode and deposition on the anode are observed for the ageing performed at $55^{\circ} \mathrm{C}$, while Fe dissolution and deposition are not observed at $-20^{\circ} \mathrm{C}$. Using atomic force microscopy (AFM), the surface conductivity is examined, which shows only minor degradation for the cathodes aged at $-20^{\circ} \mathrm{C}$. The cathodes aged at $55^{\circ} \mathrm{C}$ exhibit micrometer size agglomerates of nanometer particles on the cathode surface. The results indicate that cycling at higher SOC ranges is more detrimental and low temperature cycling mainly affects the anode by the formation of plated Li.
\end{abstract}

\section{Graphic abstract}

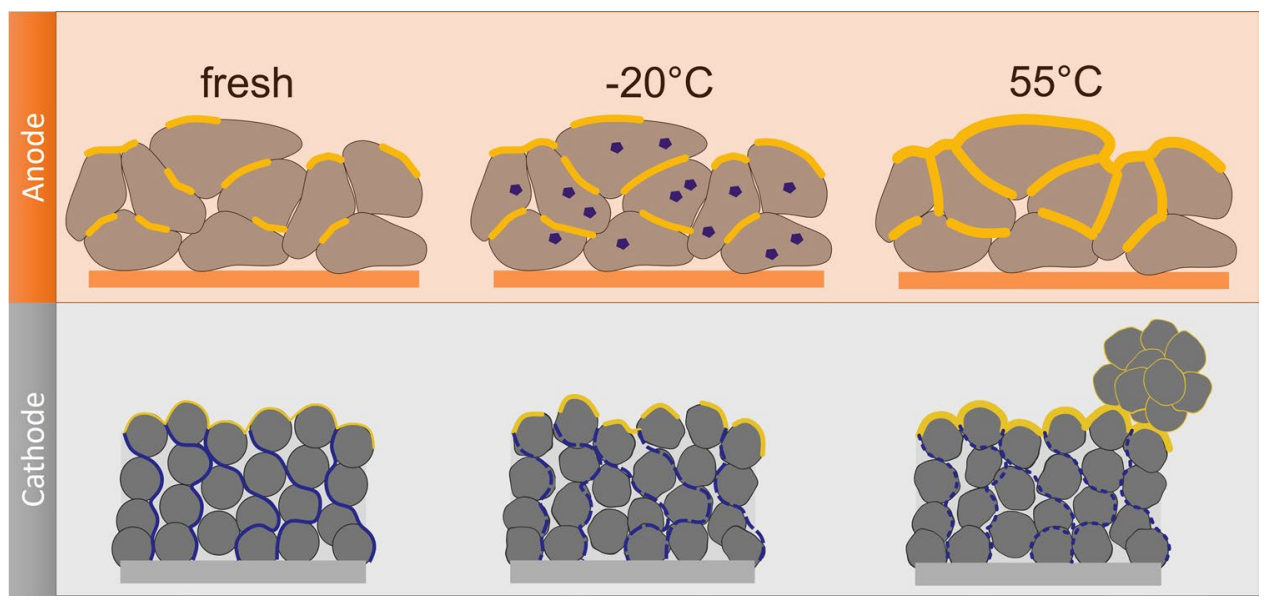

Keywords Iron dissolution $\cdot$ Vanadium dissolution $\cdot \mathrm{Li}$-ion $\cdot \mathrm{Li}$-plating $\cdot \mathrm{LiF}$ crystals $\cdot$ Degradation

Electronic supplementary material The online version of this article (https://doi.org/10.1007/s10800-020-01465-6) contains supplementary material, which is available to authorized users.

M. Simolka

Matthias.simolka@hs-esslingen.de

Extended author information available on the last page of the article

\section{Introduction}

Energy storage devices are receiving more and more attention due to the shift from fossil to renewable energy sources for the power grid and the electrification of the 
mobility sector. The focus is especially on lithium ion batteries, due to their relatively high energy density, low selfdischarge, falling costs and scalability in battery packs. However, even after roughly 30 years of development, many drawbacks still exist which limit the further utilisation and competitiveness. $\mathrm{LiFePO}_{4}$ (LFP) is a promising cell chemistry with potential to overcome all current drawbacks. It offers a relatively high working potential $(3.5 \mathrm{~V}$ vs. $\left.\mathrm{Li} / \mathrm{Li}^{+}\right)$and specific capacity of roughly $170 \mathrm{mAh} \mathrm{g}^{-1}$. The use of iron and phosphorus makes it a sustainable choice, since the materials are abundant and less toxic compared to $\mathrm{Co}, \mathrm{Ni}$ and $\mathrm{Mn}$ [1]. It was firstly introduced by Padhi et al. [2,3] and continuously improved since then. The main drawbacks of LFP are the low electronic and ionic conductivity. Additionally, for the ionic conductivity, the diffusion is highly anisotropic, due to the olivine structure of the material with $1 \mathrm{D}$ transport. Electronic $\left(10^{-7}\right.$ to $\left.10^{-9} \mathrm{~S} \mathrm{~cm}^{-1}\right)$ and ionic conductivity $\left(10^{-11}\right.$ to $10^{-20}$ $\mathrm{m}^{2} \mathrm{~s}^{-1}$ ) values in the literature span over several magnitudes and are still under debate [4]. Moreover, the reaction mechanism is assumed to follow either a 'core-shell' or 'domino' mechanism $[2,4,5]$. These difficulties show that the material is still not entirely understood and further analysis and research is necessary to clarify the underlying mechanisms leading to the different observations and parameter values. Regarding the degradation mechanisms, the scientific community is in overall agreement, that $\mathrm{Fe}$ dissolution and Li consumption during ageing are mainly responsible for the capacity fading [6-10]. The effect of the cathode surface layer on the capacity fading is not clear yet and is assumed to be negligible [11,12] or likewise affecting the capacity fading and impedance increase [7, $9,13]$. Post-mortem analysis techniques are useful tools to gain further insight into the degradation mechanisms and their dependencies on the ageing parameters like temperature, current and cycling range of the state-of-charge (SOC) (or depth-of-discharge, DOD). Scanning electron microscopy (SEM) in combination with energy dispersive $\mathrm{X}$-ray spectroscopy (EDX) is widely used to analyse material structure and element distributions of electrodes. Lewerenz et al. used SEM and EDX to analyse the covering layer formed on the anode surface [14]. They observed a compact and dense surface layer containing $\mathrm{Li}, \mathrm{Fe}$ and electrolyte decomposition products. The compact layer can deactivate parts of the electrodes and contribute to the capacity fading and increase of internal resistance [14]. In combination with focused ion beam cutting techniques (FIB), it can be used to generate a 3D model of the electrodes and further analyse the ageing. Scipioni et al. use FIB-SEM to generate 3D models of aged LFP cathodes and observe a decrease of the particle size distribution and agglomeration of carbon black particles [15]. Wang et al. used SEM and EDX to track the corrosion of LFP cathodes and demonstrated the negative impact of moisture onto the Fe dissolution process [16]. Next to EDX as elemental mapping technique, X-ray photoelectron spectroscopy (XPS) is a widely utilised technique to analyse the chemical composition of material surfaces. Regarding the LFP cathode, Koltypin et al. [17], Aurbach et al. [18] and Hellqvist et al. [13] studied the cathode surface and observed mainly $\mathrm{LiF}$ and $\mathrm{P}-\mathrm{O}$ and $\mathrm{P}-\mathrm{F}$ compounds on the surface, when $\mathrm{LiPF}_{6}$ is used as an electrolyte salt. The surface layer composition is similar to the one found on the anode side, which mainly consists of inorganic compounds like $\mathrm{Li}_{2} \mathrm{O}, \mathrm{LiOH}$ and $\mathrm{LiF}$ and organic species such as $\mathrm{ROCO}_{2} \mathrm{Li}, \mathrm{ROLi}$ (with R representing a alkyl group), $\mathrm{Li}_{2} \mathrm{CO}_{3}$ and polycarbonates [19]. Another microscopy technique used for the degradation of electrodes is atomic force microscopy (AFM). Ramdon et al. used in situ AFM to follow the changes in size of one LFP particle and found an size variation of $25 \%$, depending on state of lithiation [20]. Steinhauer et al. used in-situ AFM to follow the SEI evolution during the first cycle on crystalline carbon and observed dynamic surface structures with a potential dependent speed of growth [21]. Hiesgen et al. used AFM to analyse the morphology of sulphur cathodes depending on the binder material and observed a decrease of the electronic surface conductivity after ageing, which correlated with the capacity decay [22]. Wu et al. analysed aged $\mathrm{LiCoO}_{2}$ cathode surfaces and observed an increase in grain size and surface roughness and a decrease of the surface potential and material stiffness. They attributed these changes to the loss of lithium, the fracturing and agglomeration of particles and the generation of a surface layer from electrolyte decomposition products [23].

Several studies performed post-mortem analyses of commercial $\mathrm{LiFePO}_{4}$ cells using a variety of ageing parameters, such as different temperatures and current loads and analysed the electrodes afterwards [9, 10, 13, 14, 24, 25]. These studies show, that cycling at elevate temperatures promotes the dissolution of $\mathrm{Fe}$ from the cathode and the capacity fading is mainly caused by loss of lithium inventory due to the generation of surface layers and loss of active material.

The results presented here add additional insight into the degradation of commercial $\mathrm{LiFePO}_{4}$ cells. In particular, additional influences of the DOD is shown for Fe dissolution as a known degradation mechanisms and the importance of vanadium dissolution is shown for the first time. Furthermore, unknown degradation mechanisms with respect to $\mathrm{LiF}$ deposition, decrease in surface conductivity and the occurrence of higher amount of oxygenated species for the ageing at $-20^{\circ} \mathrm{C}$ compared to $55^{\circ} \mathrm{C}$ are reported. 


\section{Experimental}

The cycling and ageing protocol is as well reported in [26] and the main points will be stated here.

\subsection{Cycling of commercial cells}

We used commercial $26650 \mathrm{LiFePO}_{4}(26650-\mathrm{M} 1 \mathrm{~b})$ cells with nominal 2.5 Ah capacity from A123 Systems LLC. for our analysis. The cells are cycled using the last part of the "worldwide harmonised light vehicles test procedure" (WLTP) ageing profile (AP1). Additionally, to increase and speed up the ageing, the current was doubled, to generate a second test protocol (AP2). The cycling used two different DOD: $50 \%$ DOD (SOC 100-50\%) and 100\% DOD (SOC $100-0 \%)$. For each ageing group, a set of three cells was used. The cells were cycled using AP1 or AP2 until they reached the specified discharge capacity, based on the DOD. Afterwards, they were charged using 1C until 100\% SOC and the dynamic current profile restarted. The cycling was conducted at $55{ }^{\circ} \mathrm{C}$ and $-20{ }^{\circ} \mathrm{C}$. After 2000 Ah total discharge capacity passed through the cells during the ageing process, the protocol was stopped and post-mortem analysis was conducted.

The temperatures are chosen, firstly, to accelerate the aging of the cells and secondly, since these temperatures represent the minimum and maximum of the temperature operation range of the manufacturers data sheet for these cells. In addition, these temperatures are only slightly lower for the minimum temperature $\left(-15^{\circ} \mathrm{C}\right)$ and in comparable range for the maximum temperature $\left(+35^{\circ} \mathrm{C}\right)$, as they are observed as ambient temperatures for example in the USA [27]. The authors are aware of the thermal control system inside the modern automobiles, which regulates the temperature of the battery module during operation. However, during long resting times, the thermal control system is inactive and at least at the beginning of the automotive operation, the battery module is exposed to non-optimized temperatures.

\subsection{Sample preparation}

After ageing, the cells were discharged to $0 \%$ SOC using $1 \mathrm{C}$ (regarding nominal capacity), transferred into an argon filled glovebox (MBraun, Germany) and disassembled. Samples were cut out of the electrode sheets from around the first current tab and from the electrode side facing the inside of the cell. Afterwards, the samples were rinsed using dimethyl carbonate (DMC, Sigma Aldrich, Alfa Aesar) and stored inside a glovebox.

\subsection{SEM, AFM and XPS analysis}

SEM analysis was conducted using a Jeol JSM-7200F equipped with a Bruker Quantax EDX system. The samples were quickly transferred from the glovebox into the SEM to limit the exposure to air. Cross-section cuts were conducted using an unfocused Ar ion beam (Jeol IB-19520 CCP, 6 kV for $4 \mathrm{~h}$ ) equipped with a sample transfer chamber, to avoid any contact with the ambient air during the preparation process. AFM measurements were performed using a Bruker Icon installed inside an argon-filled glovebox and equipped with Bruker PeakForce QNM (quantitative nanoscale mechanical characterization) and PeakForce TUNA (tunneling AFM) module. For the AFM analysis, we use (i) the height image, which represents the sample topography, (ii) the Peak Force Error, which is the feedback signal for the set-point control and serves as a representation of the sample surface, without the influence of height differences, (iii) the adhesion, which is the force needed to detach the AFM probe from the sample surface and (iv) the Peak Current, which is the measured electrical current during the time of the highest force. For the conductivity measurements, a bias voltage of $3.0 \mathrm{~V}$ was applied between tip and sample. Commercially available AFM tips from NT-MDT (Etalon HA $\mathrm{FM} / \mathrm{W} 2 \mathrm{C}+, 75 \mathrm{kHz}, 3.5 \mathrm{~N} / \mathrm{m}$ ) with an electrical conductive $\mathrm{W}_{2} \mathrm{C}$ coating are used. Analysis of AFM measurements was conducted using NanoScope Analysis 1.9 software.

The XPS analysis was conducted using an $\mathrm{Al} \mathrm{K \alpha}$ source with an energy of $1486.6 \mathrm{eV}$ and a hemispherical analyser (Thermo Scientific ESCALAB 250) at a base pressure of $2 \times 10^{-10}$ mbar. Spectra were energy calibrated with reference to the $\mathrm{Ag} 3 \mathrm{~d}_{3 / 2}$ signal of a clean etched silver surface. Spectra are displayed normalised, and numerical peak signal fitting was carried out using Voigt peak shapes using OriginLab software. Depth profiling was carried out by $\mathrm{Ar}^{+}$ ion bombardment at argon pressure of $\sim 2.5 \times 10^{-8}$ mbar and with an average sample current of $2.0 \mu \mathrm{A}$.

\section{Results and discussion}

\subsection{Cell capacity fading over ageing}

The capacity fading follows a linear trend from the beginning to the end for the cells aged at 50\% DOD. For the cells aged at $100 \%$ DOD, the capacity fading starts to level during the ageing. The levelling is more pronounced for the cells aged at $-20{ }^{\circ} \mathrm{C}$ compared to $55{ }^{\circ} \mathrm{C}$ (Fig. 1). The cells aged at $-20^{\circ} \mathrm{C}$ using $100 \%$ DOD exhibit a noticeable capacity decline at the beginning of the ageing process and only afterwards the levelling of the capacity fading is observed. For both temperatures, the ageing profiles using 50\% DOD exhibit a higher capacity fading compared to $100 \%$ DOD. At 


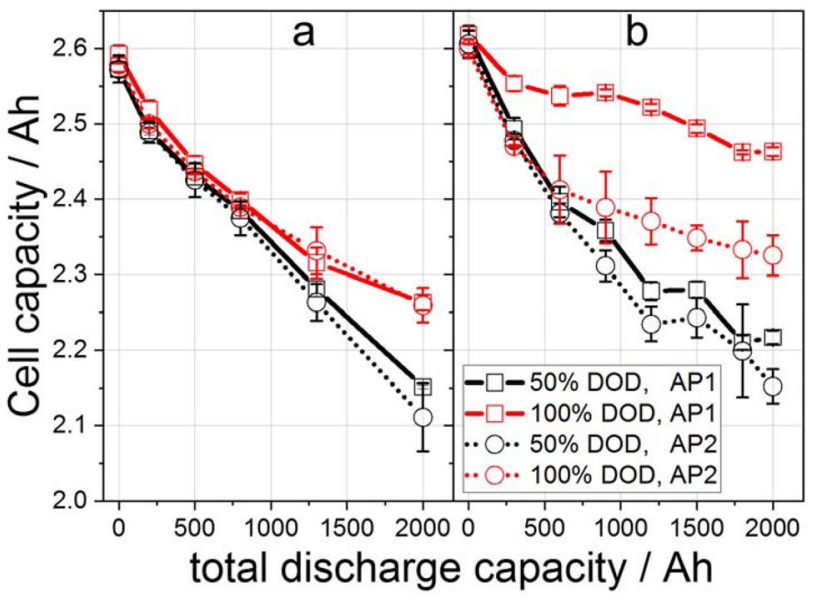

Fig. 1 Capacity decay of cells aged at $55^{\circ} \mathrm{C}$ (a) and $-20{ }^{\circ} \mathrm{C}$ (b) using AP1 and AP2 and 50\% and 100\% DOD [26]

$55^{\circ} \mathrm{C}$, the difference between AP1 and AP2 is nearly negligible. At $-20{ }^{\circ} \mathrm{C}$, the ageing at $50 \%$ DOD with AP1 and with AP2 shows likewise nearly the same capacity decline over ageing. Only the cells aged with 100\% DOD exhibit a distinct difference in the capacity fading. However, with AP2 and $100 \%$ DOD, most of the capacity decline is observed during the first 600 Ah total discharge capacity. Afterwards, the slope of the following capacity decline is practically the same for $100 \%$ DOD with AP1 and with AP2. The degradation within one ageing group is homogeneous, as can be observed by the small error bars in the capacity. Therefore, we used one or two cells from each group for post-mortem analysis.

\subsection{Structure and morphology of anode surfaces}

The anode surfaces clearly exhibit some changes compared to the fresh anode surface, but show a similar morphology for the same temperature. The anodes of cells aged with AP1 are not shown here, but they show similar results compared to the AP2 anode surfaces. The anode surfaces of a fresh anode at the beginning of life (BOL) show graphite flakes with nearly no coverage (Fig. 2a and illustration in b). The edges of the graphite flakes are clearly visible. It has to be noted, that the anode surfaces underwent washing with DMC. Therefore, any surface layer is removed that is not stable. The anode surfaces of the cells aged at $55^{\circ} \mathrm{C}$ are entirely covered with a surface layer (Fig. 2c, $d$ and illustration in e). As mentioned earlier, one major mechanism contributing to the capacity decline is the loss of lithium inventory (LLI). This is based on the continuous consumption of $\mathrm{Li}$ in the surface layer. High temperatures lead to the formation of a less stable, thicker and more porous SEI, which continuously dissolves and reforms [28-30]. Therefore, the cycling at $55^{\circ} \mathrm{C}$ consumes $\mathrm{Li}$ in the surface layer generation. The generated surface layer which is observed in the SEM images is stable enough to remain on the anode surface at the end of life (EOL), even after washing with DMC. A noticeable difference in surface morphology between the $50 \%$ DOD and 100\% DOD cycling in Fig. 2c and d is not
Fig. 2 SEM images of anode surfaces from different ageing profiles with the corresponding illustrations. Fresh (a), aged $50 \%$ DOD with AP2 (c), aged $100 \%$ DOD with AP2 at $55{ }^{\circ} \mathrm{C}$ (d) and 50\% DOD with AP2 (f) and $100 \%$ DOD with AP2 (g) at $-20{ }^{\circ} \mathrm{C}$. Illustration for the fresh anode in $\mathbf{b}$, anodes surfaces aged at $55^{\circ} \mathrm{C}$ in $\mathbf{e}$ and $-20^{\circ} \mathrm{C}$ in $\mathbf{h}$. The images show a magnification of 5.000 and 60.000 for the inset [inset (e) only 10.000]. The fresh and at $-20{ }^{\circ} \mathrm{C}$ aged anodes shows sharp edges, while the anodes aged at $55^{\circ} \mathrm{C}$ exhibit a smooth surface coverage
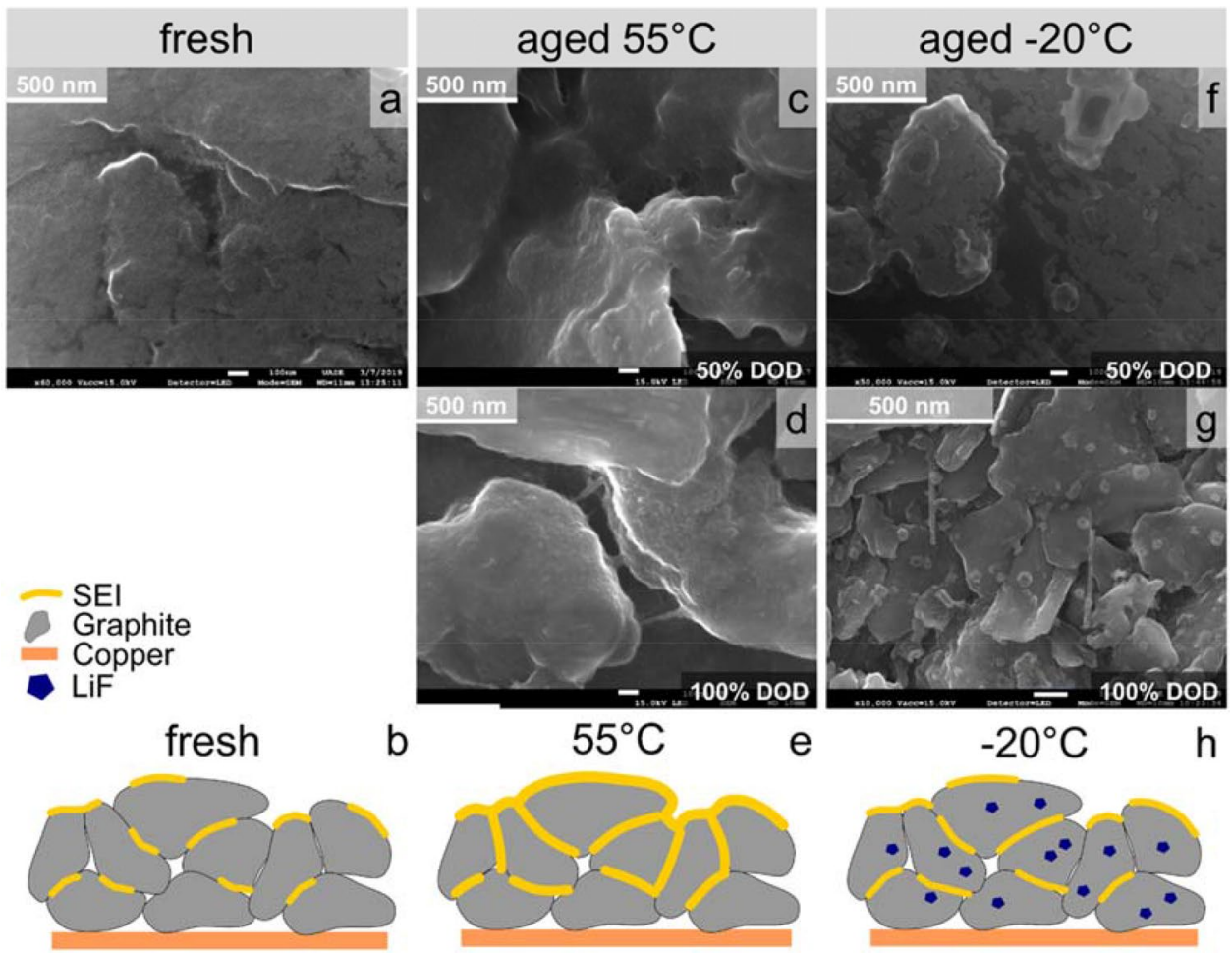
observed. Ageing at $-20^{\circ} \mathrm{C}$ did not generate a dense surface layer, as it is observed for the anodes aged at $55{ }^{\circ} \mathrm{C}$. The covering of the graphite flakes shows similar features as for the fresh anode (Fig. 2f). However, similar structures and precipitation on the anode surfaces aged at $-20{ }^{\circ} \mathrm{C}$, similar to the anodes aged at $55^{\circ} \mathrm{C}$, indicate electrolyte deposition on the anode surface, but in a smaller extend (see Fig. 2g, illustration $2 \mathrm{~h}$ and Figure S1d and e). For SEM images with lower magnification see Figure S1. Additionally, small crystal-like structures of up to $500 \mathrm{~nm}$ developed, which could indicate $\mathrm{LiF}$, since $\mathrm{LiF}$ crystals have been observed before on aged anodes [31, 32]. The crystals are found in both samples cycled at $-20^{\circ} \mathrm{C}$, but not on the anode aged at $55{ }^{\circ} \mathrm{C}$.

Next to the SEI layer on the anodes, the anodes aged at $-20{ }^{\circ} \mathrm{C}$ exhibited $\mathrm{Li}$ plating. The formation of plated $\mathrm{Li}$ is independent from the cycling profile, since it is found on anodes aged with 50\% DOD with AP1 and 100\% DOD with AP2 (Fig. 3). Li plating contributes to LLI, if Li is irreversibly plated. Moreover, the irreversibly plated $\mathrm{Li}$ can deactivate anode and cathode material, since covered surfaces on the anode and opposite to that on the cathode are no longer electrochemically active. Since the cells are disassembled in discharged state, the plated Li was not stripped off the anode surface during the discharge process. Therefore, the observed Li plating is irreversible and contributes to the capacity fading of the cells aged at $-20^{\circ} \mathrm{C}$. The plated $\mathrm{Li}$ formed large connected islands with a net-like structure on the top.

The anode surfaces were additionally examined using AFM. In Fig. 4, the height and the Peak Force Error (PFE) images of the anode surfaces are displayed. The fresh anode shows the typical large graphite flakes, which exhibit a flat surface (Fig. 4a and b). This is easily observed in the inset of the PFE image, which displays a zoom into the PFE image with an image size of $5.1 \mu \mathrm{m}$ side length. During conductivity measurements, the fresh anode showed electrically conductive areas, which was not observed for any other sample (not shown here). Therefore, the flat surface of the graphite flakes and the measurable electrical conductivity indicate a very thin or not existing SEI on the fresh anode after washing. Moreover, this indicates, that the first characterisation cycles and formation did not generate a stable and thick SEI yet. The anode surface from the cell aged at $55^{\circ} \mathrm{C}$ exhibitsas already seen in the SEM images in Fig. $2 b-$ a covering layer on the graphite flakes (Fig. $4 \mathrm{c}$ and d). Especially in the PFE, the morphological changes of the graphite flakes are clearly visible (see inset of PFE). The surface roughness increased due to ageing by $5 \%$, probably due to the formation of the rough SEI structure on top of the smooth graphite flakes. Therefore, washing of the anode surface did not remove all of the SEI, a considerable amount remained on the anode surface. This suggests a more stable and thicker SEI layer, compared to the BOL. The AFM images of the other anodes aged at $55{ }^{\circ} \mathrm{C}$ are shown in Figure S2. The anodes exhibit a surface coverage on all of the graphite flakes similar to Fig. $4 \mathrm{c}$ and d. The anode surface of the cell aged using 50\% DOD with AP2 at $-20{ }^{\circ} \mathrm{C}$ exhibits an increase in surface roughness by $3 \%$, which is mainly due to the precipitation of the crystal-like structures with roughly 200-600 nm diameter on the anode surfaces. The graphite flakes likewise exhibit an increase of the surface roughness, due to the remaining, partially covering layer. However, the surface layer does not cover all graphite flakes entirely, since some smooth and flat locations on the graphite flakes are still observed (marked by blue ellipses). The anode surface of the cell aged at $100 \%$ DOD with AP2 at $-20{ }^{\circ} \mathrm{C}$ contains as already observed in the SEM images in Fig. 3 an islandlike covering layer, which is attributed to the $\mathrm{Li}$ plating (marked by red arrows). Conductivity measurements using
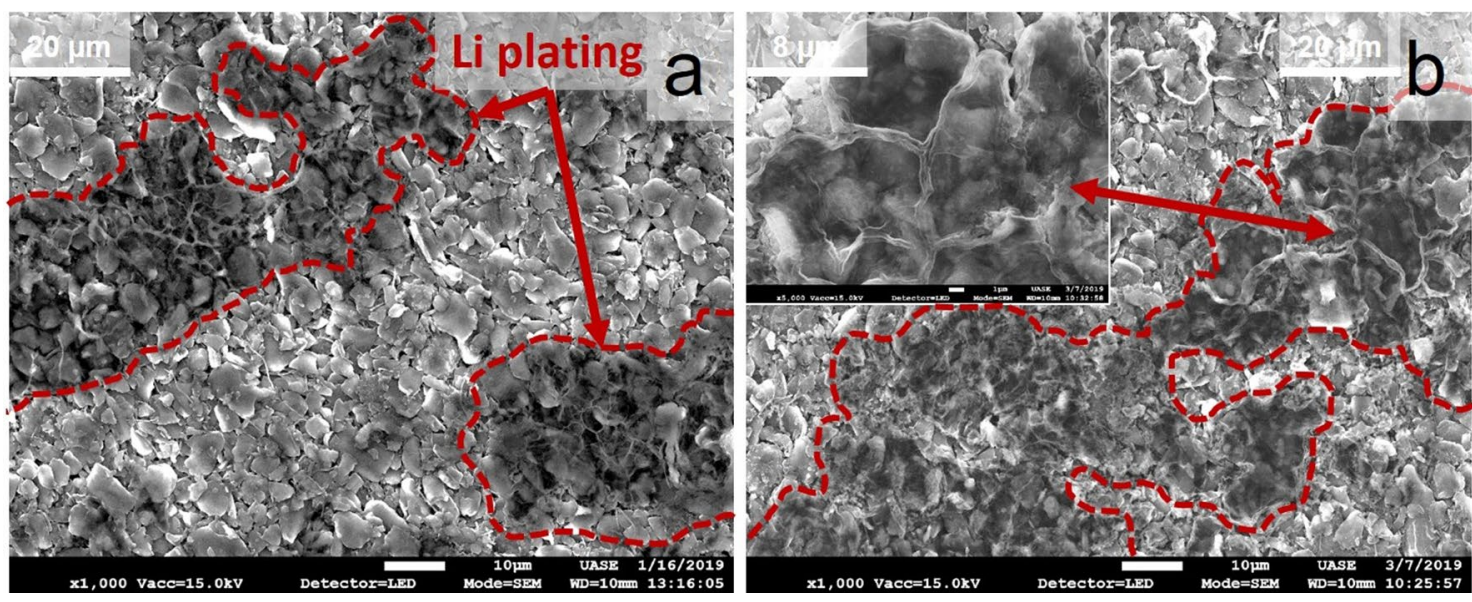

Fig. 3 SEM images of anode surfaces showing Li plating, aged at $-20{ }^{\circ} \mathrm{C}$ using 50\% DOD, with AP1 (a) and 100\% DOD, with AP2 (b) 

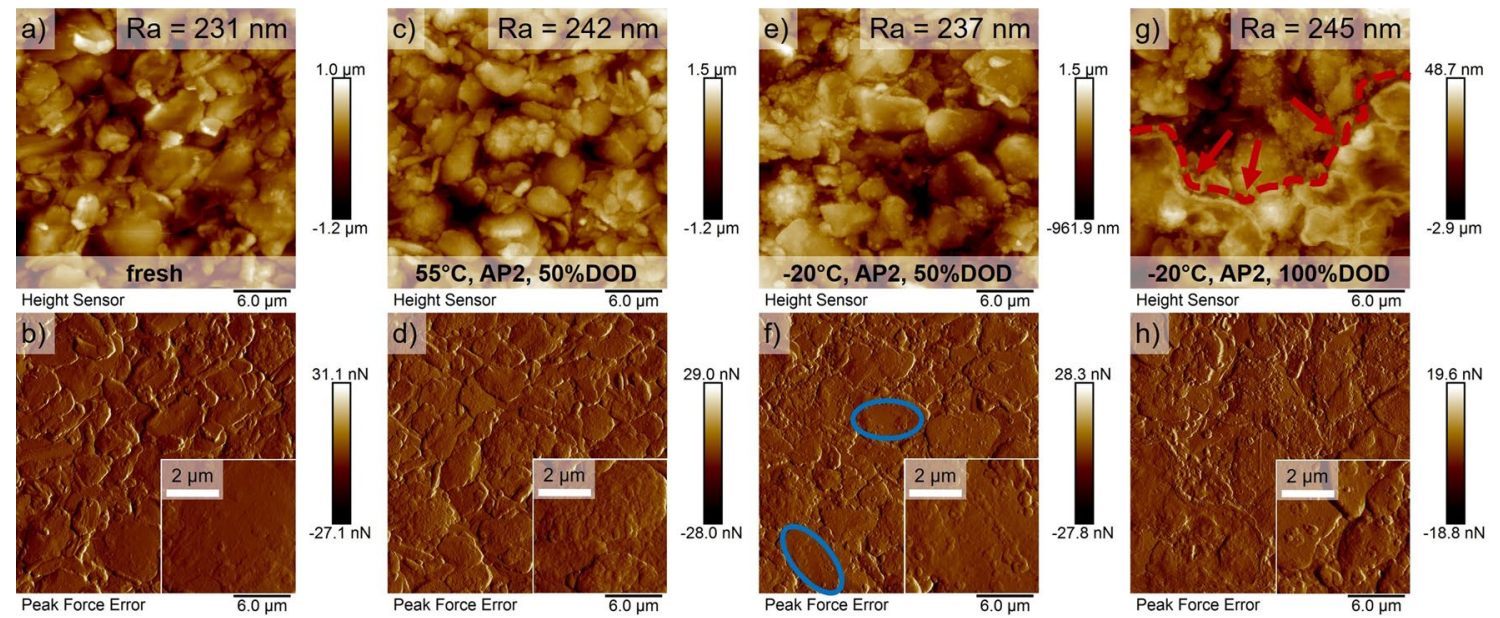

Fig. 4 AFM images showing height (top row) and Peak Force Error (bottom) of the fresh (a, b), aged at $55^{\circ} \mathrm{C}$ using AP2, 50\% DOD (c, d), aged at $-20{ }^{\circ} \mathrm{C}$ using AP2, 50\% DOD (e, f) and $-20{ }^{\circ} \mathrm{C}$ using

the AFM reveal no measurable current, which indicates electrically isolated Li plating (not shown here). The roughness increase by $6 \%$ is due to the crystal-like features, a layer on the graphite flakes and the plated Li. The AFM images of the other anodes aged at $-20^{\circ} \mathrm{C}$ are shown in Figure S3. The measurements indicate a surface layer covering parts of the graphite flakes, while some flakes exhibit a flat and smooth surface with a distinct change in adhesion, which indicates the bare graphite flakes. Therefore, the cycling at $-20{ }^{\circ} \mathrm{C}$ leads to a less pronounced surface coverage of the graphite flakes, compared to ageing at $55^{\circ} \mathrm{C}$. Several studies show a temperature dependent SEI growth and thickness over ageing, with higher temperatures leading to thick and homogeneous and lower temperatures to thin and non-uniform SEI layers [30, 33-36]. These observations confirm that temperature is a significant driving force for the reaction rate leading to the formation of the SEI layer. This relation explains the observed overall surface coverage of the graphite flakes for the anodes aged at $55^{\circ} \mathrm{C}$ (Fig. $4 \mathrm{c}$, d and Figure S2) and the only partial coverage of graphite flakes for the anodes aged at $-20^{\circ} \mathrm{C}$ (Fig. 4e-h and Figure S3).

\subsection{Chemical compositions of anode close-to-surface material and surface layers}

The chemical composition of the anode surfaces was analysed using EDX and XPS. We used an acceleration voltage of $15 \mathrm{kV}$ for the EDX measurements to be able to detect the $\mathrm{Fe} \mathrm{K} \alpha$ line. As the information depth with this method is $1-3 \mu \mathrm{m}$, in comparison to only a few $\mathrm{nm}$ in XPS. EDX results represent close-to-surface material composition, and XPS results represent the topmost surface layers. The anode surfaces contained, in addition to $\mathrm{C}$, mainly $\mathrm{O}, \mathrm{F}, \mathrm{P}, \mathrm{Fe}$ and
AP2, 100\% DOD $(\mathbf{g}, \mathbf{h})$. The blue ellipses are indicating flat surfaces on graphite flakes and the red arrows and the dashed line indicate $\mathrm{Li}$ plating

$\mathrm{V}$. The precipitation of phosphorus and oxygen is based on the reduction of electrolyte and of electrolyte salt $\left(\mathrm{LiPF}_{6}\right)$ on the anode surface, since the anode potential is lower than the chemical stability window of these components. The mass content of $\mathrm{P}$ increases due to cycling by the factor of $2-4$. Within one ageing profile (AP1 or AP2), the anode surface cycled at 50\% DOD exhibits a higher P content compared to the $100 \%$ DOD cycling at the same ageing profile (see Fig. 5). This is explained by the well-known observation that cycling at higher SOC leads to more pronounced SEI generation compared to lower SOC cycling [32, 37, 38]. The cycling at $50 \%$ DOD leads to a longer duration at high SOC ranges (compared to 100\% DOD) of the cells with more electrolyte and salt decomposition. Furthermore, an

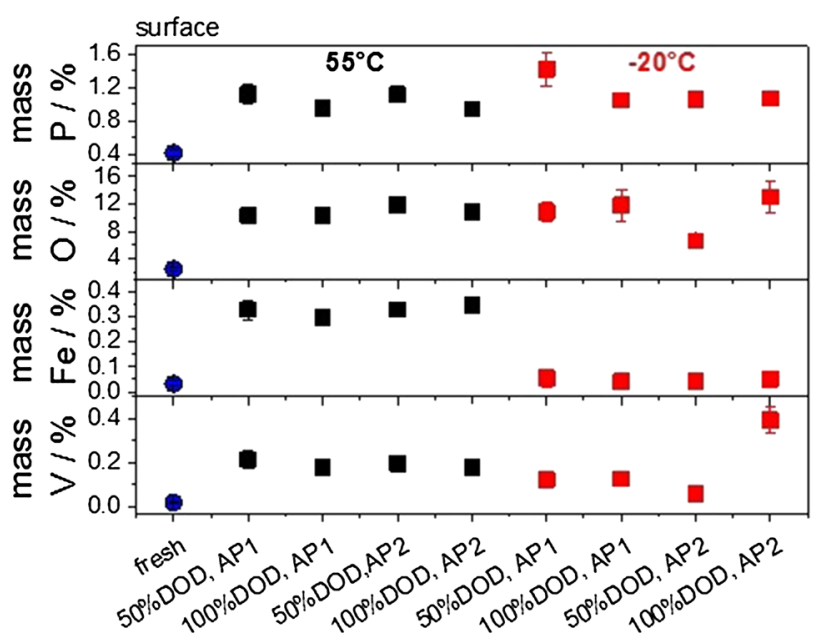

Fig. 5 EDX analysis of anode surfaces regarding the $\mathrm{P}, \mathrm{O}, \mathrm{Fe}, \mathrm{O}$ and $\mathrm{V}$ mass content 
important difference between the 50\% DOD cycling and the $100 \%$ DOD cycling is the number of charge-discharge cycles. One cycle for the 50\% DOD cells represents $1.25 \mathrm{Ah}$ cycle $^{-1}$, leading to roughly 1600 cycles until EOL, while for the $100 \%$ DOD cells $\left(2.5 \mathrm{Ah} \mathrm{cycle}^{-1}\right)$ only about 800 cycles are performed until EOL is reached. The higher amount of potential cycles for the 50\% DOD cycling leads to a thicker SEI, which consumed more Li during the ageing. The anodes aged at $-20{ }^{\circ} \mathrm{C}$ exhibit likewise an increase of $\mathrm{P}$ and $\mathrm{O}$ on the surfaces in a similar extent, even though a less pronounced SEI is observed in the SEM and AFM images. This is due to the plated $\mathrm{Li}$, which reacts with the electrolyte to form decomposition products on the anodes aged at $-20^{\circ} \mathrm{C}$, even when the surface of the graphite flakes is not covered entirely, as it is the case for the graphite flakes aged at $55^{\circ} \mathrm{C}$.

Similar trends for the oxygen content as already found for phosphorus are observed on the anodes aged at $55^{\circ} \mathrm{C}$. The mass of oxygen increased due to ageing by a factor of 4-6. The underlying origin is the same as for phosphorus. However, at $-20^{\circ} \mathrm{C}$, the anode surfaces show a different behaviour. The cells aged at 100\% DOD show a higher oxygen content compared to the cells aged with 50\% DOD. This observation could be based on the existence of plated $\mathrm{Li}$, which reacts with oxygen from the electrolyte or during the transfer of the sample from the glovebox into the SEM observation chamber. Petzl and Danzer [39] assume that the Li plated at lower SOC (100\% DOD cycling) is thicker and more stable compared to high SOC plating (50\% DOD cycling).

The observed Fe dissolution exhibits the assumed temperature dependency. The anode surfaces aged at $55^{\circ} \mathrm{C}$ show clearly the presence of $\mathrm{Fe}$, while the anodes aged at $-20^{\circ} \mathrm{C}$ do not show any significant amount. The Fe dissolution does not show any clear dependency on the DOD. This clearly shows that high temperatures promote the Fe dissolution, while it is suppressed at low temperatures. Lastly, vanadium is observed on the anode surfaces. Due to the low electronic and ionic conductivity of LFP, it is doped with multivalent cations $\left(\right.$ like $\mathrm{V}^{3+}$ ) to improve the conductivity [40]. All transition metals commonly used in $\mathrm{Li}$ ion batteries are dissolved from the cathode into the electrolyte upon ageing [41, 42]. As will be shown later, the mass content of $\mathrm{V}$ decreased in the cathodes after ageing, indicating dissolution of $\mathrm{V}$ from the cathode and precipitation on the anode surface. The $\mathrm{V}$ content is generally higher at the anodes cycled at $55{ }^{\circ} \mathrm{C}$. A notable exception is the anode aged at $100 \%$ DOD with AP2 at $-20^{\circ} \mathrm{C}$, which showed a distinct higher amount as compared to the other cells. The origin of this observation is not entirely clear yet, but might indicate inhomogeneous deposition of $\mathrm{V}$. The transition metals $\mathrm{V}$ and Fe act as catalysts at the anode surface for the formation and subsequent growth of the SEI $[6,43]$. The deposition of transition metals is in addition hindering the $\mathrm{Li}$ intercalation into the graphite anode by clogging anode pores [14, 43, 44]. The increase of the surface layer related resistance was analyzed using EIS in [26]. It was observed, that the cells aged at $55^{\circ} \mathrm{C}$ exhibit a surface layer related increase of resistance between 12 and $27 \%$. The formation of surface layers consumes $\mathrm{Li}$, which is afterwards lost for subsequent cycling, and deactivates anode material by blocking the intercalation and de-intercalation process.

Figure 6 shows the XPS spectra of anodes aged at $-20^{\circ} \mathrm{C}\left(1^{\text {st }}\right.$ and $2^{\text {nd }}$ row each) and $55{ }^{\circ} \mathrm{C}$ (3rd and 4 th row each) using 50\% DOD with AP1 (2nd and 4th row) and AP2 (1st and 3rd row) in comparison to the fresh anode (5th row see also Table 1 for peak assignment). The bulk spectra refer to the surface laid open after ion etching for a total time of $2660 \mathrm{~s}$, while the surface spectra were recorded before. In the $\mathrm{C} 1 \mathrm{~s}$ surface spectra, the fresh anode shows four peaks around 284, 287, 288 and $292 \mathrm{eV}$. The peak around $284 \mathrm{eV}$ is assigned to $\mathrm{C}-\mathrm{C}$ and $\mathrm{C}-\mathrm{H}$ species. After ageing at $55^{\circ} \mathrm{C}$, the peak is no longer observed, while at $-20^{\circ} \mathrm{C}$ these species are still found. The vanishing of the peak around $284 \mathrm{eV}$ for the anodes aged at $55^{\circ} \mathrm{C}$ indicates a thick and homogeneous surface layer covering the entire anode surface. Since the peak is still observed in the anodes aged at $-20^{\circ} \mathrm{C}$, the surface layer is only partially covering the anode, as it was already observed in the AFM measurements (Fig. 4). The peaks at $287 \mathrm{eV}$ and $288 \mathrm{eV}$ are assigned to $\mathrm{C}-\mathrm{O}$ and $\mathrm{C}=\mathrm{O}$ bonds, respectively. The peak at $292 \mathrm{eV}$ is assigned to decomposition products of the carbonate-based electrolyte. Interestingly, the carbonate-based peak is not observed in the aged samples, neither in the surface layer nor in the bulk. After ion etching for $2660 \mathrm{~s}$, the bulk material of all anodes exhibits only the two peaks of the $\mathrm{C}-\mathrm{C} / \mathrm{C}-\mathrm{H}$ and the $\mathrm{C}-\mathrm{O}$ species. Two peaks around $685 \mathrm{eV}$ and $689 \mathrm{eV}$ dominate the F1s surface spectra. They are attributed to $\mathrm{Li}_{x} \mathrm{PO}_{y} \mathrm{~F}_{z}$ and $\mathrm{Li}_{x} \mathrm{PF}_{z}$, respectively, which are decomposition products of $\mathrm{LiPF}_{6}$. However, PVDF (polyvinylidene difluoride) as an assumed binder material in the electrodes can influence the peak around $689 \mathrm{eV}$, due to the $\mathrm{C}-\mathrm{F}$ bond. $\mathrm{Li}_{\mathrm{x}} \mathrm{PO}_{\mathrm{y}} \mathrm{F}_{\mathrm{z}}$ is additionally observed in the $\mathrm{P} 2 \mathrm{p}$ surface spectra of all anodes at $136 \mathrm{eV}$. The anode aged at $-20{ }^{\circ} \mathrm{C}$ with AP1 exhibits a higher relative intensity for the $\mathrm{Li}_{\mathrm{X}} \mathrm{PF}_{\mathrm{z}}$ peak in the $\mathrm{F} 1 \mathrm{~s}$ spectrum compared to the other anodes. The $\mathrm{P} 2 \mathrm{p}$ surface spectra points likewise to a higher $\mathrm{Li}_{\mathrm{x}} \mathrm{PF}_{\mathrm{z}}$ concentration on the anodes aged at $-20{ }^{\circ} \mathrm{C}$ compared to $55^{\circ} \mathrm{C}$, since the peaks around $138 \mathrm{eV}$ (assigned to $\mathrm{Li}_{\mathrm{x}} \mathrm{PF}_{\mathrm{z}}$ ) are only observed in the low temperature ageing. An additional peak appears around $685 \mathrm{eV}$ for the anodes aged at $-20{ }^{\circ} \mathrm{C}$ in the F1s bulk spectra, which is assigned to LiF. The attribution of LiF crystals to the observed features in the AFM images for the anodes aged at $-20{ }^{\circ} \mathrm{C}$ is therefore verified by the presence of this peak (only detected for the anodes aged at $-20^{\circ} \mathrm{C}$ ). For the fresh anode and the anodes aged 

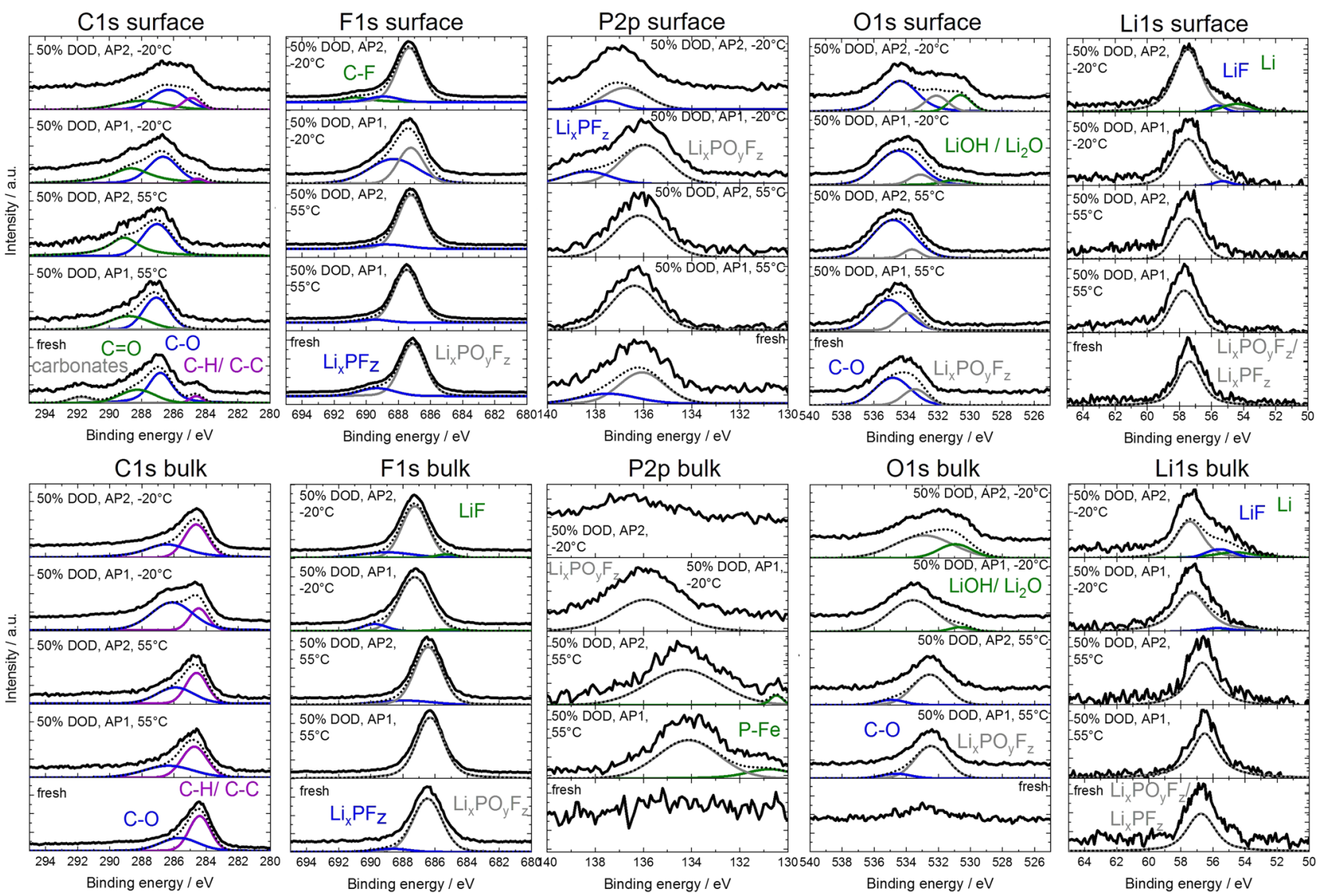

Fig. 6 XPS spectra of the anode surfaces showing the C1s, F1s, P2p, $\mathrm{O} 1 \mathrm{~s}$, and Li1s spectra at the surface (top) and after sputtering for $2660 \mathrm{~s}$ (indicated as bulk, bottom set of spectra). The 1st row shows

at $55{ }^{\circ} \mathrm{C}$, the $\mathrm{O} 1 \mathrm{~s}$ surface spectra contains two peaks at $535 \mathrm{eV}$ and $533.5 \mathrm{eV}$ that are assigned to $\mathrm{C}-\mathrm{O}$ species and $\mathrm{Li}_{\mathrm{x}} \mathrm{PO}_{\mathrm{y}} \mathrm{F}_{\mathrm{z}}$, respectively. The anodes aged at $-20{ }^{\circ} \mathrm{C}$ exhibit an additional peak around $530.5 \mathrm{eV}$. This peak is attributed to $\mathrm{LiOH}$ or $\mathrm{Li}_{2} \mathrm{O}$ species $[45,46]$. The bulk material of the fresh anode generates no significant $\mathrm{O} 1 \mathrm{~s}$ peak anymore. Contrary, the aged anodes still contain the peaks, which are found on the surface, which indicates a thicker and more stable SEI layer for all aged anodes as compared to the fresh state. In the $\mathrm{P} 2 \mathrm{p}$ bulk spectra, the $\mathrm{Li}_{\mathrm{x}} \mathrm{PO}_{\mathrm{y}} \mathrm{F}_{\mathrm{z}}$ peaks of the anodes aged at $55{ }^{\circ} \mathrm{C}$ are shifted towards lower binding energies, compared to the $-20{ }^{\circ} \mathrm{C}$ data, therefore indicating lower oxidation states. The relative peak intensity of the anode aged at $-20^{\circ} \mathrm{C}, 50 \%$ DOD with AP2 is very low and non-existing for the fresh anode, which is in agreement with the aforementioned vanishing of the $\mathrm{Li}_{\mathrm{x}} \mathrm{PO}_{\mathrm{y}} \mathrm{F}_{\mathrm{z}}$ peak in the $\mathrm{O} 1 \mathrm{~s}$ spectra around $533.5 \mathrm{eV}$. The P2p bulk spectra of the anodes aged at $55{ }^{\circ} \mathrm{C}$ exhibit an additional peak at around $130.5 \mathrm{eV}$. $\mathrm{P}$ atoms coordinated to a $\mathrm{Fe}$ atom are assumed to generate this additional peak at lower binding energies. Since Fe dissolution is not the anode from a cell aged at $-20{ }^{\circ} \mathrm{C}, 50 \%$ DOD with AP2; the 2nd row $-20{ }^{\circ} \mathrm{C}, 50 \%$ DOD with AP1; 3rd row $55{ }^{\circ} \mathrm{C}, 50 \%$ DOD with AP1; 4th row $55^{\circ} \mathrm{C}, 50 \%$ DOD with AP2 and 5th row in fresh state

observed for the anodes aged at $-20^{\circ} \mathrm{C}$, such a peak is not expected and neither observed for these anodes. $\mathrm{Li}_{x} \mathrm{PO}_{\mathrm{y}} \mathrm{F}_{z}$ and $\mathrm{Li}_{\mathrm{x}} \mathrm{PF}_{\mathrm{z}}$ are mainly dominating the $\mathrm{L} 1 \mathrm{~s}$ spectra at $57 \mathrm{eV}$. The cells aged at $-20{ }^{\circ} \mathrm{C}$ exhibit additionally a peak around $56 \mathrm{eV}$, indicating $\mathrm{LiF}$ and a small peak around $54 \mathrm{eV}$, which is assigned to plated Li species which was already observed in SEM and AFM images. The surface and bulk Li1s spectra show similar results.

The elements in the SEI layer are essentially similar for the anodes aged at $55^{\circ} \mathrm{C}$ and $-20^{\circ} \mathrm{C}$. However, some deviations are observed: i) only for the anodes aged at $-20^{\circ} \mathrm{C}$, $\mathrm{LiF}$ is observed, ii) additional species such as $\mathrm{LiOH}$ or $\mathrm{Li}_{2} \mathrm{O}$ (indicating $\mathrm{Li}$ plating) are only observed in the anodes aged at $-20{ }^{\circ} \mathrm{C}$, iii) on the anodes aged at $-20^{\circ} \mathrm{C}$, a higher amount of $\mathrm{Li}_{\mathrm{x}} \mathrm{PF}_{\mathrm{z}}$ is present compared to the anodes aged at $55^{\circ} \mathrm{C}$, iv) the anodes aged at $-20^{\circ} \mathrm{C}$ show lithium species, as already observed in the SEM and AFM images, and v) for the anodes aged at $55^{\circ} \mathrm{C}$, due to $\mathrm{Fe}$ dissolution, which is already observed in the EDX analysis, an additional peak due to $\mathrm{P}$ atoms coordinated to $\mathrm{Fe}$ atoms, is observed. 

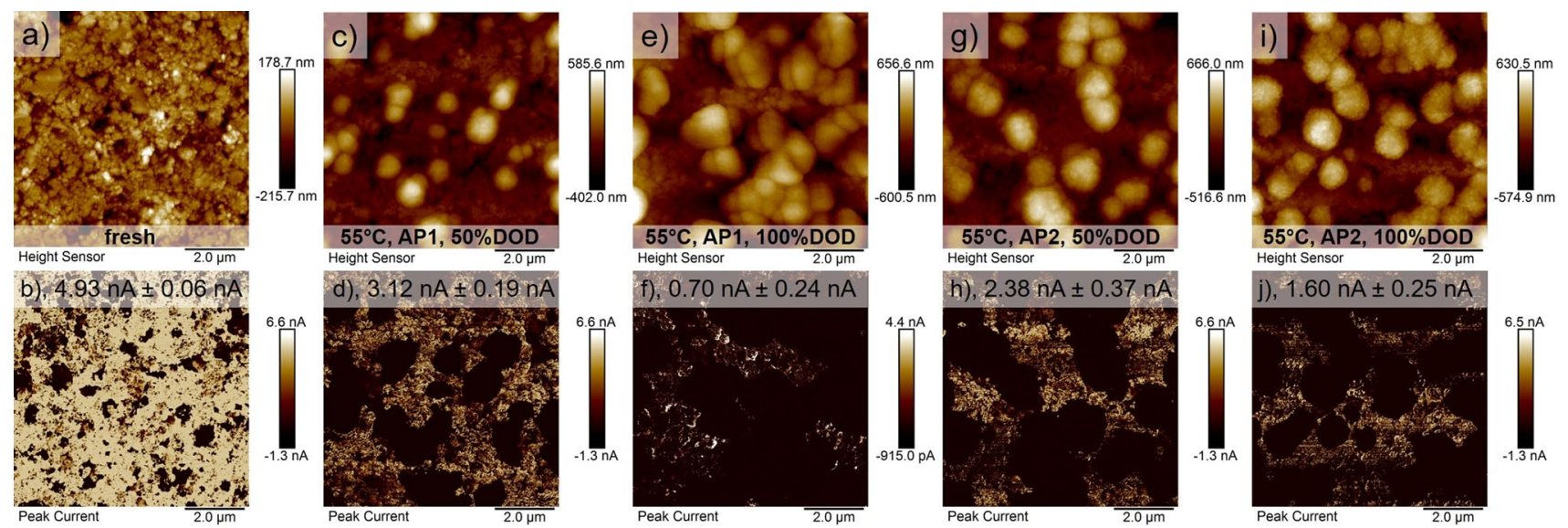

Fig. 7 AFM surface images of fresh cathodes (a, b) and cathodes aged at $55{ }^{\circ} \mathrm{C}$ using $50 \%$ DOD with AP1 (c, d), 100\% DOD with AP1 $(\mathbf{e}, \mathbf{f}), 50 \%$ DOD with AP2 $(\mathbf{g}, \mathbf{h})$ and $100 \%$ DOD with AP2 $(\mathbf{i}, \mathbf{j})$. Top

\subsection{Structure and morphology of cathode surfaces}

The fresh cathode surface is highly conductive (about $80 \%$ of the measured surface area is conductive) and consists of small particles of roughly $50-200 \mathrm{~nm}$ in diameter (Fig. 7a, b). After the ageing at $55^{\circ} \mathrm{C}$, the cathode surfaces are covered by electrically non-conductive agglomerates having a diameter of roughly 0.5 to $1 \mu \mathrm{m}$. The surface coverage is consistently higher for the $100 \%$ DOD profile aged with AP1 or AP2 (Fig. 7e, f and i, j) compared to the $50 \%$ DOD profile (Fig. 7c, d and g, h). The agglomerates consist of smaller particles of roughly $15-100 \mathrm{~nm}$ in diameter, which show a lower adhesion compared to the agglomerate-free cathode surface (see Figure $\mathrm{S} 4$ for higher magnification). The adhesion is governed by electrostatic interactions between tip and surface and remaining electrolyte material. Influences of a water meniscus on the adhesion play an important role but can be excluded here, due to the dry argon atmosphere. Using a positive bias voltage, the particles showing a low adhesion are expected to be $\mathrm{LiFePO}_{4}$ particles, while the high adhesion is assigned to binder and electrolyte material due to presence of charges and a higher mechanical pulloff force of the tip from the surface, induced by remaining electrolyte. The appearance of negative adhesion is based on the existence of negatively charged LFP particles $\left[\mathrm{Li}_{(1-\mathrm{x})} \mathrm{FePO} 4\right]^{\mathrm{x}-}$, due to the loss of lithium inventory over cycling, while applying a positive bias voltage. The loss of lithium inventory is next to the loss of active material the main influence for the capacity decay over aging (see [26] for more information on the degradation of the cells). The nanometer particles forming the agglomerates must be covered with a thicker, isolating surface layer or exhibit a degradation of the conductive carbon coating. Otherwise, the agglomerates would still exhibit a measurable current row shows the cathode surface topography and the bottom row the (peak) current. In the top of the current images, the average current magnitude of the agglomerate-free surface is given

through the conductive nanometer particle network. Zhu et al. previously observed the appearance of large surface agglomerates for cycled $\mathrm{LiMnO}_{2}$ cathodes [47]. In their study, the agglomerates are assumed to be generated by fragmentation of particles due to cyclic induced stress by continuous lithiation and delithiation and consecutive agglomeration of nanometer particles, which is in agreement with the observed composition of the agglomerates here. Therefore, the continuous lithiation and delithiation leads to cracking and fragmentation of large LFP particles and subsequent agglomeration generates the micrometre size agglomerates. The observed lack of conductivity on these agglomerates indicates disconnection to the electrode electrical network and therefore also a loss of active material due to the generation of an electrochemical inactive phase.

Since the agglomerates are electrically insulating, the quantity of agglomerates controls the overall surface conductivity. The conductivity decreased by $40 \%$ to $70 \%$ compared to the fresh cathode (see Fig. 9a top). Apart from the agglomerates, the surface conductivity is influenced by (i) the isolating surface layer, (ii) degradation of carbon coating and (iii) the contact loss of the particle to the conductive electrode network. The roughness of the cathode surface, which is not covered by the agglomerates, decreased compared to the fresh cathode surface by roughly $25 \%$ to $50 \%$ (Fig. 9a bottom). Since we exclude the large agglomerates for the surface roughness analysis, the presence of the agglomerates does not affect the resulting roughness measurements. Most other surface roughness studies on cathodes $\left(\mathrm{LiCoO}_{2}, \mathrm{LiMnO}_{2}\right.$ and $\left.\mathrm{LiFePO}_{4}\right)$ report an increase of the surface roughness over ageing, which is due to the generation of smaller particles due to fragmentation [23, 47, 48]. The decrease of the agglomerate-free surface roughness is based on the remaining surface layer, which was not 
removed during the sample preparation process (see Fig. 9b for an illustration). Since the samples are measured exsitu, the sample preparation process influences the surface roughness of the samples. For example $\mathrm{Wu}$ et al. used an extensive procedure with acetone and ethanol to wash the cathode surfaces several times, which presumably removed all remaining electrolyte and measured an increase of the surface roughness after ageing [23]. Contrary, we employed a more delicate procedure with DMC in a single process to wash off electrolyte and no further surface treatment for the analysis.

Nevertheless, Kostecki et al. [49] and Demirocak and Bushan [50] observed likewise a decrease in surface roughness after cyclic and calendric ageing of $\mathrm{LiN}_{0.8} \mathrm{Co}_{0.2} \mathrm{O}_{2}$ and $\mathrm{LiFePO}_{4}$ cathodes, respectively. While Demirocak and Bushan did not elaborate further on this observation, Kostecki et al. attribute this to the formation of a deposit which is not enhanced by electrochemical cycling [49]. The formation of an electrolyte layer on the cathode surface reduces the surface roughness of the analysed aged cathodes. We assume the deposit to exhibit only a thin layer thickness, since the AFM measurements still show a measurable current in these areas. The observed decrease of surface conductivity, which is observed by the reduced magnitude of the measured current in the aged cathode surfaces, is therefore attributed to the degradation of carbon coating on the particle and loss of electrical contact to the electrode conductivity network. The surface layer does not seem to electrically isolate the cathode surface, since the agglomerate-free cathode surfaces still exhibit a measurable current (see also Figure S4 for a higher magnification of the agglomerate-free cathode surface). The degradation of the carbon coating and loss of electrical contact leads to a higher electrode resistance, which is observed in the lower absolute current in the peak current measurements (ranging from 0.70 to $3.12 \mathrm{nA}$ for the aged cathodes) compared to the fresh cathode (4.93 nA).

Contrary to the cathodes aged at $55^{\circ} \mathrm{C}$, the cathode surfaces aged at $-20{ }^{\circ} \mathrm{C}$ and prepared using the same procedure for the sample analysis, exhibit nearly no change in surface morphology and structure (Fig. 8). The surface morphology consists of small particles and exhibits a decrease of the conductive area of only 5-20\% (see Fig. 9 top) and the
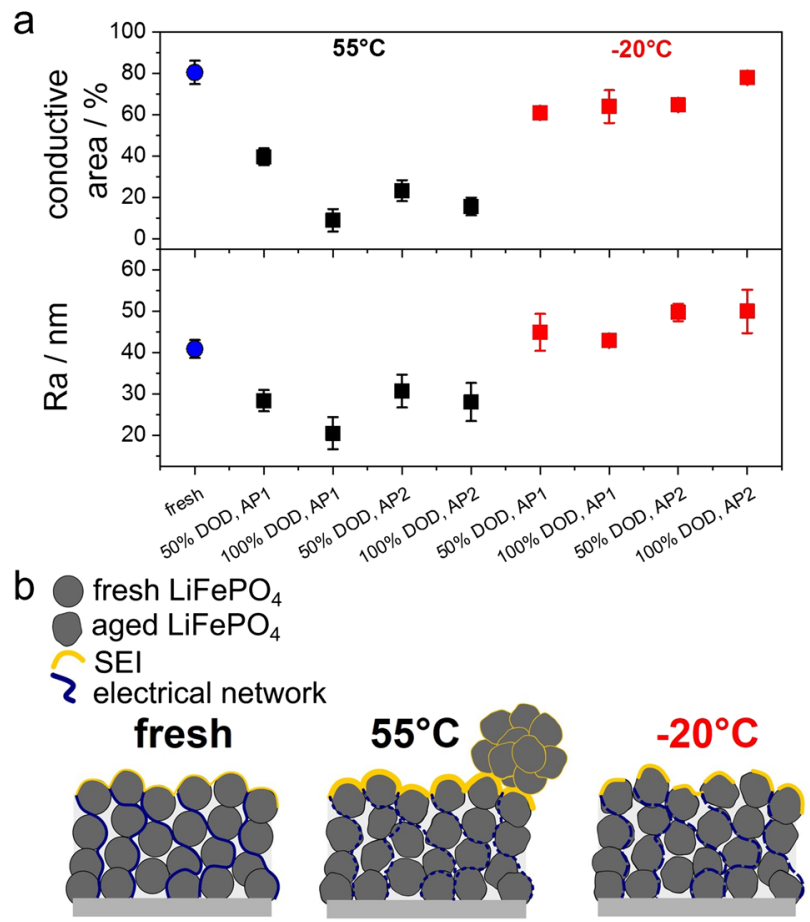

Fig. 9 Analysis of AFM surface measurements of cathodes aged at $55^{\circ} \mathrm{C}$ and $-20{ }^{\circ} \mathrm{C}$ showing in a the conductive area in the top and the surface roughness in the bottom row and in $\mathbf{b}$ the illustration of the surface layer and electrical network degradation of the fresh cathode and the cathodes aged at $55^{\circ} \mathrm{C}$ and $-20{ }^{\circ} \mathrm{C}$
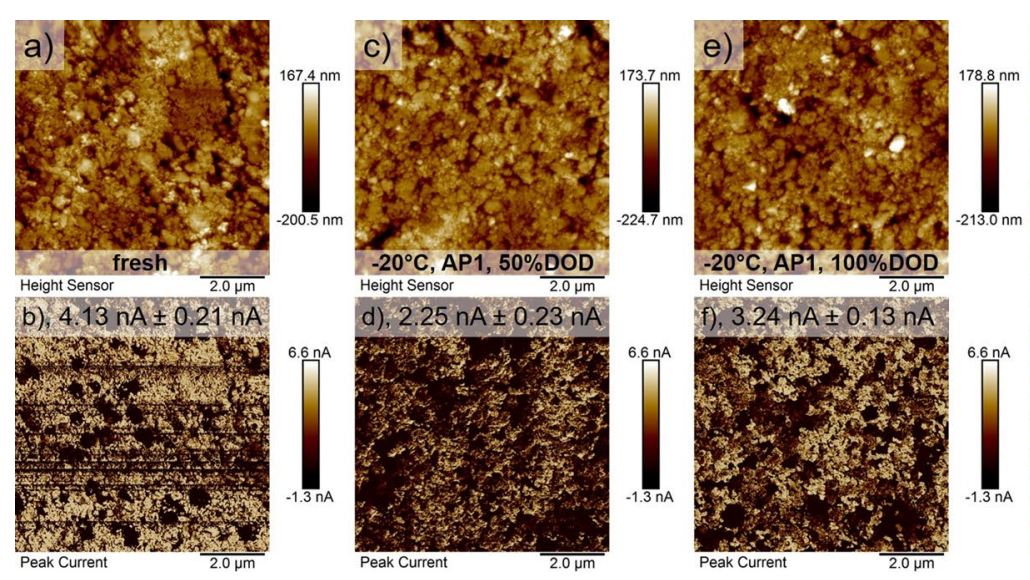
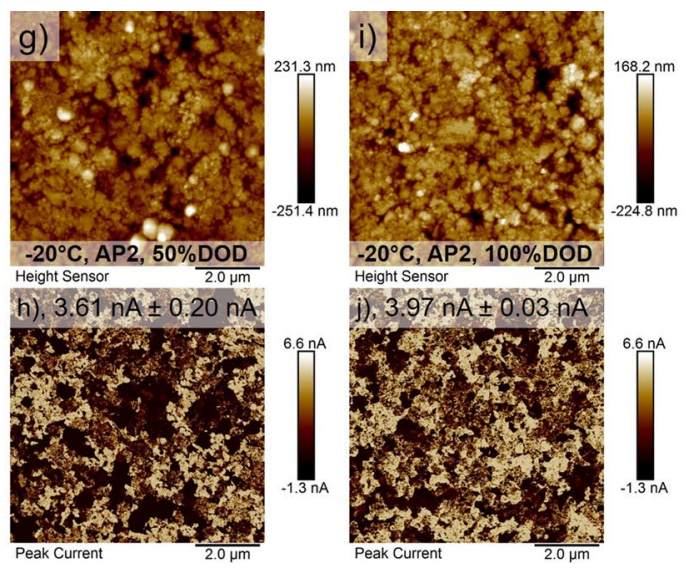

Fig. 8 AFM surface images of fresh cathodes (a, b) and cathodes aged at $-20{ }^{\circ} \mathrm{C}$ using $50 \%$ DOD with AP1 (c, d), 100\% DOD with AP1 (e, f), 50\% DOD with AP2 (g, h) and 100\% DOD with AP2 (i, j). Top row shows the cathode surface topography and the bottom row the (peak) current. In the top of the current images, the average current magnitude of the agglomerate-free surface is given 
surface roughness increased by 5-22\% compared to the fresh cathode (Fig. 9 bottom). The overall magnitude of the measurable current reduced in a lower extend for the cathodes aged at $-20^{\circ} \mathrm{C}$ (ranging from 2.25 to $3.97 \mathrm{nA}$ ) compared to the cathodes aged at $55^{\circ} \mathrm{C}$. The modest reduction of the conductive area in AFM images is attributed to loss of electrical contact of particles to the electrode conductivity network. Carbon coating degradation does not influence the surface conductivity, but leads to a reduction in the absolute values of the current magnitude due to resistance increase of the electrode. The increase of the surface roughness is attributed to an inhomogeneous surface layer, which does not cover the cathode surface completely, and cracking and fragmentation of LFP particles. This is based on the assumption that thicker, homogeneous and complete surface layers are generating a smooth and flat surface layer, while the bare cathode and a cathode with only small and limited coverage exhibits a rough surface, due to the structure of the uncovered LFP particles. The assumption is summarized in the illustration in Fig. 9b. The thin surface layer has presumably a negligible influence on the overall surface conductivity.

The surface conductivity of the cathodes aged at $55^{\circ} \mathrm{C}$ decreased intensely compared to the fresh cathode surface and the cathodes aged at $-20{ }^{\circ} \mathrm{C}$. However, the cathodes with the highest decrease of surface conductivity $(100 \%$ DOD with AP1 and AP2) show a decrease of capacity at the EOL of $12 \%$ and $13 \%$, while the other cells aged at $50 \%$ DOD with AP1 and AP2 show a capacity decrease of $16 \%$ and $17 \%$, respectively, but a higher share of conductive area after ageing. A similar trend is observed for the cathodes aged at $-20{ }^{\circ} \mathrm{C}$, which show an almost constant surface conductivity within the group after ageing, but differ in the remaining cell capacity (Fig. 1). Therefore, the decrease of the cathode surface conductivity does not seem to have a direct impact on the remaining cell capacity. This observation is plotted in Figure S5, which displays the independency of the remaining cell capacity on the surface conductive area. Next to the cell capacity, the power capabilities, which would be influenced by a resistance increase of the cells, is not affected by the observed reduction of surface conductivity. This observation was reported before by the authors in Figure S11 [26], which depicts the evolution of the internal cell resistance of the electrodes (called $\mathrm{R}_{\text {total }}$ ). For the cells aged at $-20{ }^{\circ} \mathrm{C}$ and the cell aged at $55^{\circ} \mathrm{C}$ with $100 \%$ DOD using AP2, the resistance stays nearly constant throughout the ageing. For the cell aged at $55^{\circ} \mathrm{C}$ with $50 \%$ DOD using AP2 the resistance increases by $70 \%$, however, the cathode exhibits a higher share of surface conductive area compared to the cell aged at $55^{\circ} \mathrm{C}$ with $100 \%$ DOD using AP2. Therefore, especially the power capabilities of the cell aged at $55^{\circ} \mathrm{C}$ with $100 \%$ DOD using AP2 should show any influence by the reduced share of the surface conductive area, which is, however, not observed. Changes in the power characteristics would be influenced by modifications in the cell resistance, which are, however, only observed for the cell aged at $55^{\circ} \mathrm{C}$ using 50\% DOD, but these are based on different degradation mechanisms (Fe-dissolution, damages to the internal, electrically conductive electrode network and deactivation of before electrochemically active material) and not based on the surface conductivity of the cathodes.

The decrease of surface roughness indicates coverage of particles on the cathode surface, which reduces the overall roughness for the cathodes aged at $55^{\circ} \mathrm{C}$. Ageing with $100 \%$ DOD leads to a more homogeneous coverage layer, since the surface roughness is smaller compared to the 50\% DOD cycling profiles. The roughness follows the same trend as the surface conductivity, with $100 \%$ DOD exhibiting a higher decrease of the surface roughness compared to the $50 \%$ DOD counterpart. The cathodes aged at $-20^{\circ} \mathrm{C}$ exhibit an unchanged or a slightly increased surface roughness, which shows, that cycling at $-20{ }^{\circ} \mathrm{C}$ generates only very limited coverage of particles upon ageing. The increase of surface roughness is due to the cracking and fragmentation of LFP particles, which are subsequently not entirely covered by a surface layer.

\subsection{Chemical compositions of cathode close-to-surface material and surface layers}

The chemical composition of the cathode surface was analysed using EDX and XPS. The EDX analysis reveals an increase of the mass of $\mathrm{P}$ and Fe (Fig. 10). This is valid for nearly all cathode surfaces, except the cathode aged at $-20^{\circ} \mathrm{C}$ using $100 \%$ DOD with AP2, which shows only negligible variations compared to the fresh cathode. Regarding the cells aged at $55^{\circ} \mathrm{C}$, the absolute change compared to the fresh cathode surface was continuously higher for the cathode aged at AP1 than for the AP2 ageing.

The Fe content on the cathode surfaces increases for all analysed cathodes. This would be assumed for cathodes

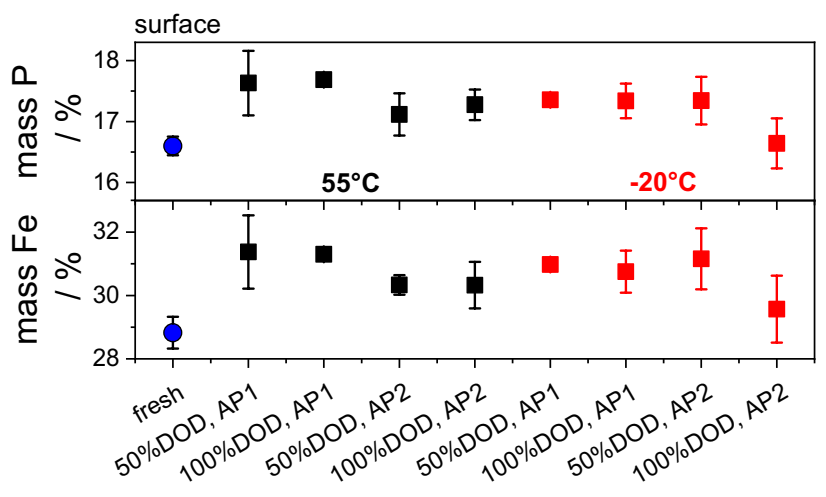

Fig. 10 EDX analysis of cathode surfaces regarding the $\mathrm{P}$ and $\mathrm{Fe}$ norm. mass content 
aged at elevated temperatures, due to Fe dissolution from the bulk. The appearance of a higher Fe content on the surface of cathodes aged at $-20{ }^{\circ} \mathrm{C}$, for which no $\mathrm{Fe}$ deposition at the anode surfaces is observed, is unexpected. Additionally, the Fe content of the cathode cross-section stays constant or increases slightly (see Fig. 12). The cathodes aged at $55^{\circ} \mathrm{C}$ exhibit an increase of the $\mathrm{Fe}$ content on the cathode surface and a decrease of the Fe content in the cross-section, which would be expected for the dissolution of Fe from the bulk into the electrolyte. This observation of the Fe content increase on the cathode surface and cross-section for the cathodes aged at $-20{ }^{\circ} \mathrm{C}$ points towards an inhomogeneous Fe redistribution inside the cathode due to ageing, since Fe dissolution towards and deposition on the anode is not observed. Phosphorus follows the same mechanism as observed for $\mathrm{Fe}$, without the dissolution into the electrolyte, since the P increase on the anode surface is attributed to electrolyte salt decomposition and SEI growth. On the cathode surfaces, a higher $\mathrm{P}$ content after ageing is observed, while for the cross-section it decreased. This observation points towards a redistribution of $\mathrm{P}$ inside the cathode material, as it is assumed for Fe.

The XPS spectra of the cathode surfaces show species similar to the anode surfaces. The $\mathrm{C}-\mathrm{C}$ and $\mathrm{C}-\mathrm{H}(284 \mathrm{eV})$ peaks are well observable in all samples and their intensities on the bulk surface increase only slightly after ion etching (Fig. 11, see also Table 2 for peak assignment). A similar observation is found in the O1s spectra for the $\mathrm{PO}_{4}{ }^{3-}$ peak at $531 \mathrm{eV}$, which is well observable. The pronounced $\mathrm{C}-\mathrm{C} / \mathrm{C}-\mathrm{H}$ and $\mathrm{PO}_{4}{ }^{3-}$ peaks indicate only partial coverage of the cathode surface as already observed in the AFM measurements (Figs. 7 and Fig. 8). The peak at $688 \mathrm{eV}$, attributed to $\mathrm{Li}_{\mathrm{x}} \mathrm{PO}_{\mathrm{y}} \mathrm{F}_{\mathrm{z}}$, dominates most of the $\mathrm{F} 1 \mathrm{~s}$ surface and bulk spectra. Only the cathode surface aged at $55{ }^{\circ} \mathrm{C}, 50 \%$ DOD with AP1 exhibits an additional and more pronounced peak at $690 \mathrm{eV}$, originating from $\mathrm{Li}_{\mathrm{x}} \mathrm{PF}_{\mathrm{z}}$ species.
The other cathode surface aged at $55{ }^{\circ} \mathrm{C}, 50 \%$ DOD with AP2 exhibits only a weak signal at $690 \mathrm{eV}$, similar to the fresh cathode. The cathodes aged at $-20^{\circ} \mathrm{C}$ do not show any observable peak at this binding energy. After ion etching, the intensity of the $\mathrm{Li}_{\mathrm{x}} \mathrm{PF}_{\mathrm{z}}$ peak increases for the cathodes aged at $55{ }^{\circ} \mathrm{C}$. The $-20{ }^{\circ} \mathrm{C}$ cathodes exhibit an additional peak at lower binding energies, which is attributed to $\mathrm{LiF}(685 \mathrm{eV})$. The $\mathrm{PO}_{4}{ }^{3-}$ peak at $133 \mathrm{eV}$ dominates the $\mathrm{P} 2 \mathrm{p}$ spectra for all cathode surfaces. On the fresh cathode, peaks indicating $\mathrm{Li}_{\mathrm{x}} \mathrm{PF}_{\mathrm{z}}$ and $\mathrm{Li}_{\mathrm{x}} \mathrm{PO}_{\mathrm{y}} \mathrm{F}_{\mathrm{z}}$ are observed at $137 \mathrm{eV}$ and $136 \mathrm{eV}$, respectively. The cathodes aged at $55{ }^{\circ} \mathrm{C}$ contain next to the $\mathrm{PO}_{4}{ }^{3-}$ peak only traces of $\mathrm{Li}_{\mathrm{X}} \mathrm{PF}_{z}$, while the cathodes aged at $-20{ }^{\circ} \mathrm{C}$ exhibit only traces of $\mathrm{Li}_{\mathrm{x}} \mathrm{PO}_{\mathrm{y}} \mathrm{F}_{\mathrm{z}}$. The $\mathrm{F} 1 \mathrm{~s}$ and $\mathrm{P} 2 \mathrm{p}$ spectra indicate that the ageing at $55^{\circ} \mathrm{C}$ leads to more pronounced precipitation of $\mathrm{Li}_{\mathrm{x}} \mathrm{PF}_{\mathrm{z}}$ over ageing compared to the ageing at $-20{ }^{\circ} \mathrm{C} . \mathrm{Li}_{\mathrm{x}} \mathrm{PF}_{\mathrm{z}}$ is formed by decomposition of $\mathrm{LiPF}_{6}$ in the electrolyte $[11,51,52]$ following reaction (1) and (2). $\mathrm{Li}_{\mathrm{x}} \mathrm{PO}_{\mathrm{y}} \mathrm{F}_{\mathrm{z}}$ is formed due to traces of water in the electrolyte and by reaction with the highly reactive $\mathrm{PF}_{5}$ through reaction (3) and (4). $\mathrm{LiF}$ is not observed on the cathode surfaces aged at $55{ }^{\circ} \mathrm{C}$, even though it is a product of the reactions (1), (2) and (4) and often found in $\mathrm{LiPF}_{6}$ based electrolytes [11, 12, 53]. High temperature cycling might promote $\mathrm{LiF}$ dissolution into the electrolyte, which could explain the missing $\mathrm{LiF}$ peaks for the cathodes aged at $55^{\circ} \mathrm{C}[46,47]$.

$\mathrm{LiPF}_{6} \rightarrow \mathrm{LiF}+\mathrm{PF}_{5}$

$2 x \mathrm{Li}^{+}+2 x \mathrm{e}^{-}+\mathrm{PF}_{5} \rightarrow \mathrm{Li}_{\mathrm{x}} \mathrm{PF}_{5-\mathrm{x}}+(2-x) \mathrm{LiF}$

$\mathrm{PF}_{5}+\mathrm{H}_{2} \mathrm{O} \rightarrow 2 \mathrm{HF}+\mathrm{PF}_{3} \mathrm{O}$

$2 x \mathrm{Li}^{+}+2 x \mathrm{e}^{-}+\mathrm{PF}_{3} \mathrm{O} \rightarrow \mathrm{Li}_{\mathrm{x}} \mathrm{PF}_{3-\mathrm{x}} \mathrm{O}+x \mathrm{LiF}$
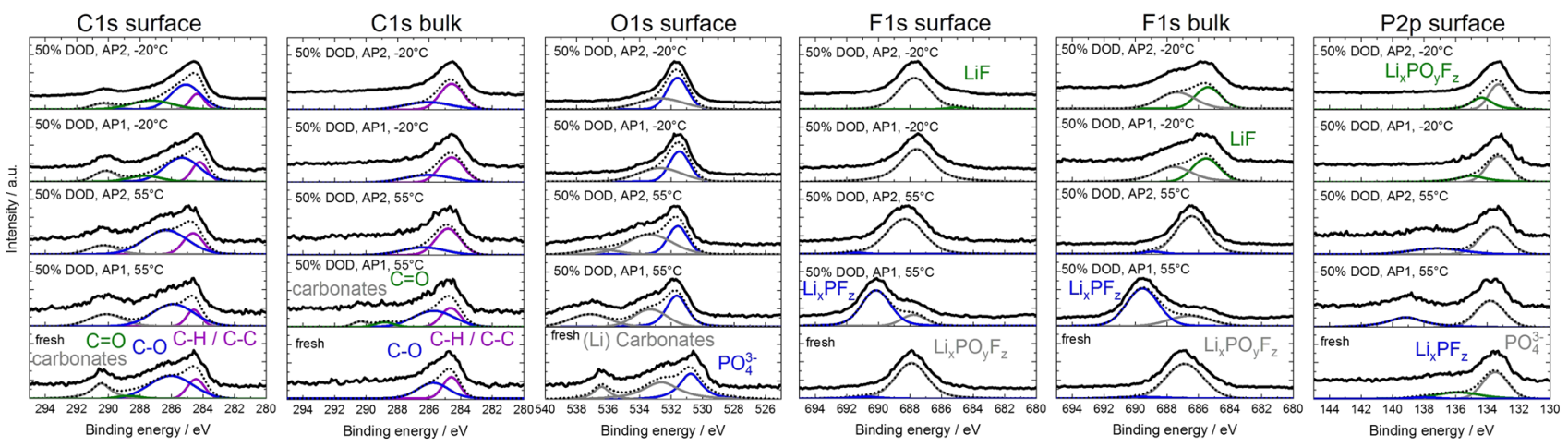

Fig. 11 XPS spectra of the cathode surfaces showing the C1s, F1s, $\mathrm{O} 1 \mathrm{~s}$ and P2p spectra at the surface and after sputtering for $2660 \mathrm{~s}$ (indicated as bulk). The 1st row shows the anode from a cell aged

at $-20{ }^{\circ} \mathrm{C}, 50 \%$ DOD with AP2; the 2 nd row $-20{ }^{\circ} \mathrm{C}, 50 \%$ DOD with AP1; 3rd row $55{ }^{\circ} \mathrm{C}, 50 \%$ DOD with AP1; 4 th row $55^{\circ} \mathrm{C}, 50 \%$ DOD with AP2 and 5th row in fresh state 


\subsection{Chemical compositions of cathode bulk material}

Next to the cathode surface, the cross-section of cathodes was investigated using EDX measurements, to analyse the changes due to cycling in the bulk material. For the cathodes aged at $55^{\circ} \mathrm{C}, \mathrm{P}$ and $\mathrm{Fe}$ show a similar trend, with a decrease of the $\mathrm{P}$ and $\mathrm{Fe}$ content for the 50\% DOD cycling and a constant or only slight decrease for the cathodes aged with $100 \%$ DOD. The decrease of the Fe content in the bulk material is in agreement with the already observed $\mathrm{Fe}$ dissolution from the cathode and migration to and deposition on the anode surface (see Fig. 5). The decrease of the P content in the cathode bulk and the increase of the $\mathrm{P}$ content on the cathode surface indicate an accumulation of $\mathrm{FePO}_{4}$ active material in the surface of the electrode and depletion in the bulk of the cathode due to cycling. This effect is more pronounced for the cathodes aged at 50\% DOD. This effect might be linked to the overall completed ageing cycles of the cathode. As explained earlier, the 50\% DOD cells completed roughly twice as many charge and discharge cycles compared to the $100 \%$ DOD cells. The higher amount of cycles leads to an inhomogeneous distribution and accumulation of active material near the surface in the cathode. The increase of the vanadium content on the anode surface is accompanied by the decrease in the cathode bulk. The decrease does not exhibit any distinct dependency on the ageing profile. Transition metal dissolution is therefore not only limited to $\mathrm{Fe}$, but also affects $\mathrm{V}$, a doping agent. The appearance of $\mathrm{V}$ dissolution into the electrolyte was already observed by Hovington et al. for $\mathrm{Li}_{1.2} \mathrm{~V}_{3} \mathrm{O}_{8}$ cathodes [54]. For the cathodes aged at $-20{ }^{\circ} \mathrm{C}$, no distinct trend for the elemental changes was detected. A decrease in the mass of $\mathrm{P}$ is observed for the cathodes aged with AP1, whereas it stays constant or increases slightly for the cathodes aged with AP2. Since the capacity fading is quite different for the cells aged with $50 \%$ DOD and $100 \%$ DOD with AP1, but similar changes

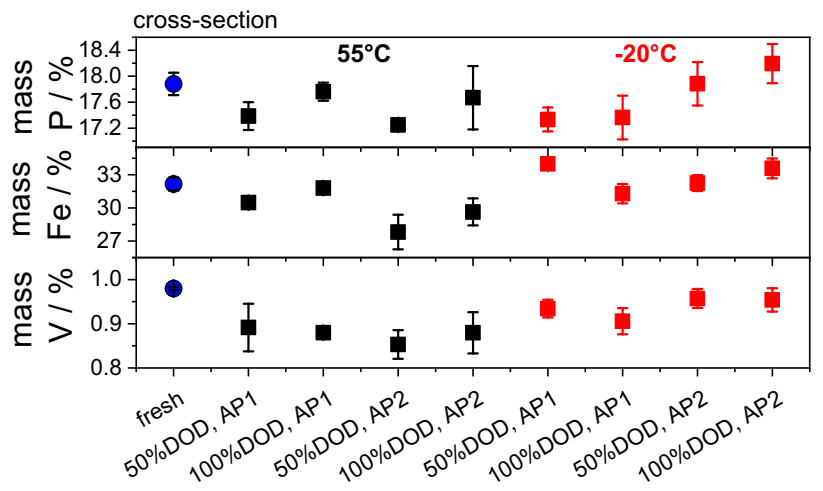

Fig. 12 EDX analysis of cathode cross-section bulk material regarding the $\mathrm{P}, \mathrm{Fe}$ and $\mathrm{V}$ norm. mass content
Table 1 Peak assignment (in eV) for the observed species on the anode surface

\begin{tabular}{lccccc}
\hline & $\mathrm{P} 2 \mathrm{p}$ & $\mathrm{F} 1 \mathrm{~s}$ & $\mathrm{O} 1 \mathrm{~s}$ & $\mathrm{Li1s}$ & $\mathrm{C} 1 \mathrm{~s}$ \\
\hline $\mathrm{C}-\mathrm{O}$ & & & 535 & & 287 \\
$\mathrm{C}-\mathrm{C} / \mathrm{C}-\mathrm{H}$ & & & & & 284 \\
$\mathrm{C}=\mathrm{O}$ & & & & & 288 \\
Carbonates & & & & & 292 \\
$\mathrm{C}-\mathrm{F}$ & 691 & & & \\
$\mathrm{Li}_{\mathrm{x}} \mathrm{PF}_{\mathrm{z}}$ & 138 & 689 & & 57 & \\
$\mathrm{Li}_{\mathrm{x}} \mathrm{PO}_{\mathrm{y}} \mathrm{F}_{\mathrm{z}}$ & 136 & 687 & 533 & 57 & \\
$\mathrm{LiF}$ & & 685 & & 56 & \\
$\mathrm{P}-\mathrm{Fe}$ & 131 & & & & \\
$\mathrm{LiOH} / \mathrm{Li}_{2} \mathrm{O}$ & & & 531 & & 287 \\
$\mathrm{Li}$ & & & & 54 & \\
\hline
\end{tabular}

over ageing are observed in the elemental analysis of the cross-section, we expect the observation in Fig. 12 to indicate heterogeneous active material distribution within the electrode for the cathodes aged at $-20^{\circ} \mathrm{C}$. If loss of active material would be responsible for the observed changes in the elemental analysis, the capacity decay over ageing would be comparable, which is however not the case for the $50 \%$ and $100 \%$ DOD cells aged with AP1. An increasing inhomogeneity for the distribution of lithium was already observed on cell level for the cells aged at $-20^{\circ} \mathrm{C}$ [26]. The reduction of the $\mathrm{V}$ content is in agreement with the observed increase on the anode surface. Interestingly, it is detected in a smaller extent for $-20{ }^{\circ} \mathrm{C}$ compared to the cathodes aged at $55^{\circ} \mathrm{C}$. $\mathrm{Fe}$ dissolution is not observed. Reduction of $\mathrm{V}$ as a doping agent can lead to electrical and ionic resistance increase in the cathode and therefore contribute to an increase of the impedance and decrease of power capabilities over ageing.

Table 2 Peak assignment (in $\mathrm{eV}$ ) for the observed species on the cathode surface

\begin{tabular}{lcccl}
\hline & $\mathrm{P} 2 \mathrm{p}$ & $\mathrm{F} 1 \mathrm{~s}$ & $\mathrm{O} 1 \mathrm{~s}$ & $\mathrm{C} 1 \mathrm{~s}$ \\
\hline $\mathrm{C}-\mathrm{C} / \mathrm{C}-\mathrm{H}$ & & & & 284 \\
$\mathrm{C}-\mathrm{O}$ & & & & 287 \\
$\mathrm{C}=\mathrm{O}$ & & & & 288 \\
Carbonates & & & & 290.5 \\
$\mathrm{Li}_{\mathrm{x}} \mathrm{PF}_{\mathrm{z}}$ & 137 & 690 & & \\
$\mathrm{Li}_{\mathrm{x}} \mathrm{PO}_{\mathrm{y}} \mathrm{F}_{\mathrm{z}}$ & 136 & 688 & 533 & \\
$\mathrm{LiF}$ & & 685 & & \\
$\mathrm{PO}_{4}{ }^{3-}$ & 133 & & 531 & \\
\hline
\end{tabular}




\section{Conclusion}

Post-mortem analyses of cathodes and anodes of commercial LFP cells aged at $55^{\circ} \mathrm{C}$ and $-20{ }^{\circ} \mathrm{C}$ and cycled with different dynamic load profiles are presented. The current intensity (difference from AP1 to AP2) has a smaller influence on the capacity fading than the DOD (see Fig. 1).

The anode surfaces aged at $55{ }^{\circ} \mathrm{C}$ show a dense surface layer on the graphite flakes and only to a small extent an electrolyte decomposition layer on the anodes aged at $-20{ }^{\circ} \mathrm{C}$. The anodes aged at $-20{ }^{\circ} \mathrm{C}$, however, reveal intense Li plating and the appearance of crystal-like features, which are presumably $\mathrm{LiF}$ crystals. $\mathrm{LiF}, \mathrm{LiOH}$ and $\mathrm{Li}_{2} \mathrm{O}$ species are observed in the XPS spectra in the anodes aged at $-20{ }^{\circ} \mathrm{C}$, but not at the anodes aged at $55{ }^{\circ} \mathrm{C}$. Fe resulting from dissolution is well observed on the anodes aged at $55^{\circ} \mathrm{C}$, while low temperature cycling completely represses Fe from dissolution. Nevertheless, $\mathrm{V}$ is observed on all anode surfaces, independent from temperature, which is similar to the decrease of the $\mathrm{V}$ content observed for the cathode bulk. The 50\% DOD profile shows consistently higher mass contents of $\mathrm{P}, \mathrm{O}$ and $\mathrm{V}$ and $\mathrm{Fe}$ (with only one exception at AP2 for $\mathrm{Fe}$ ) compared to the 100\% DOD counterpart for the ageing at $55^{\circ} \mathrm{C}$ on the anode, which indicates higher electrolyte decomposition rates due to cycling at higher SOC ranges. Ageing at $-20{ }^{\circ} \mathrm{C}$ does not show any clear pattern, neither in the aged cathode, nor in the aged anode.

The cathodes aged at $55^{\circ} \mathrm{C}$ exhibit micrometre size and electrically isolating agglomerates consisting of $\mathrm{LiFePO}_{4}$ particles. Particle cracking, fragmentation and subsequent agglomeration of the nanometer particles generate the agglomerates. The agglomerates are electrochemically inactive and responsible for loss of active material, next to the observed Fe dissolution from the cathode into the electrolyte. The remaining cathode surface, which is not covered by the agglomerates, shows an overall lower conductivity compared to the fresh cathode, indicating an additional degradation of the carbon coating on the particles and connection from the particles to the overall electrode electrical network. The surfaces of the cathodes aged at $-20{ }^{\circ} \mathrm{C}$ do not show any surface covering and show no significant change in overall surface conductivity. XPS analysis reveals higher amount of traces of $\mathrm{Li}_{\mathrm{x}} \mathrm{PF}_{\mathrm{z}}$ at the cathodes surfaces aged at $55{ }^{\circ} \mathrm{C}$, while higher amount of traces of $\mathrm{Li}_{\mathrm{x}} \mathrm{PO}_{\mathrm{y}} \mathrm{F}_{\mathrm{z}}$ are observed at the cathodes aged at $-20^{\circ} \mathrm{C}$. $\mathrm{LiF}$ is only observed at the cathodes aged at $-20^{\circ} \mathrm{C}$. The EDX analysis of cathode surfaces show an increase of the mass content of $\mathrm{P}$ and $\mathrm{Fe}$ on the surface with a decrease of $\mathrm{Fe}$ in the bulk for the cathodes aged at $55{ }^{\circ} \mathrm{C}$. The $50 \%$ DOD profiles show a higher amount of $\mathrm{Fe}$ decrease in the cathode bulk, which points towards a higher Fe dissolution rate at high SOC cycling. The bulk of the cathodes reveal a cycling temperature independent decrease of the mass content of $\mathrm{V}$, which is presumably a doping agent to increase the electrochemical performance.

The main factors leading to the capacity decay are loss of lithium inventory and loss of active material (see as well [26]). Loss of lithium inventory is for the cells aged at $55^{\circ} \mathrm{C}$ based on the formation of a surface layer on the anode side. For the cells aged at $-20^{\circ} \mathrm{C}, \mathrm{Li}$ plating is likely the main source of loss of lithium inventory, since the formation of a surface layer is observed in a smaller extend. The cathode aged at $55{ }^{\circ} \mathrm{C}$ exhibits formation of surface agglomerates consisting of active material and $\mathrm{Fe}$ dissolution from the cathode and deposition on the anode surface. A similar effect is not observed for the cathodes aged at $-20^{\circ} \mathrm{C}$. Therefore, the ageing at $55^{\circ} \mathrm{C}$ is the sum of the anode (loss of lithium inventory) and cathode (loss of active material) contribution, while for the ageing at $-20^{\circ} \mathrm{C}$, the anode (loss of lithium inventory) is the main factor influencing the capacity decay.

The key insights of the presented results are summarised as following: firstly, we show that next to the temperature, the depth of discharge is another factor influencing the $\mathrm{Fe}$ dissolution. Secondly, the formation of LiF crystals with roughly $500 \mathrm{~nm}$ in diameter are observed, but only for the cells aged at $55{ }^{\circ} \mathrm{C}$. Thirdly, structural analyses of the cathode surface show that the surface conductivity is drastically decreased for the cathodes aged at $55^{\circ} \mathrm{C}$ by the evolution of micrometer sized, electrically isolated $\mathrm{LiFePO}_{4}$ agglomerates. However, the reduction of the surface conductivity does not correlate with the capacity fading, indicating only a minor influence of electrode surface conductivity on the overall capacity fading process. Fourthly, next to the dissolution of iron, vanadium dissolution from the cathode and deposition on the anode is observed, indicating instable doping of $\mathrm{LiFePO}_{4}$ material. Fifthly, the electrolyte deposition species on the cathodes exhibit a higher amount of oxygenated species for the ageing at $-20{ }^{\circ} \mathrm{C}$ compared to $55^{\circ} \mathrm{C}$, indicating different decomposition paths. Additionally, the results confirm, that cycling at lower DOD is more detrimental than cycling using the full capacity range $[10,55]$. The manuscript is linked to another publication [26] on the tracking of cell ageing using cell level analysis techniques. The results are supposed to assist in the correct choice of operation conditions for these highly used commercial cells and cell chemistry and to present the degradation mechanisms related to the ageing. These observations reveal that cycling at elevated temperatures and higher SOC levels have a more detrimental effect on the electrode materials. Cycling at $-20{ }^{\circ} \mathrm{C}$ had only little detrimental effects on the cathodes and for the anodes it resulted mainly in the occurrence of $\mathrm{Li}$ plating. The reduction of the surface conductivity does not have any correlation with the remaining capacity, therefore, its influence on cell ageing is assumed negligible. 
Acknowledgements We thank A. Lützner and P. Gazdzicki for performing and analysing parts of the XPS measurements. The authors would like to point out the contributions made by Renate Hiesgen, who supervised all of the work until her death in November 2018. All responsibility for this publication rests with the authors.

Author contributions All authors contributed to the study conception and design. Material preparation, data collection and analysis were performed by Matthias Simolka, Jan-Frederik Heger and Indro Biswas. The first draft of the manuscript was written by Matthias Simolka and all authors commented on previous versions of the manuscript. All authors read and approved the final manuscript.

Funding Open Access funding enabled and organized by Projekt DEAL. The authors gratefully acknowledge the funding by the Federal Ministry of Education and Research within the Framework Concept "IngenieurNachwuchs" (03FH028IX4) and managed by the Project Management Agency VDI Technologiezentrum GmbH.

Data availability The datasets generated during and/or analysed during the current study are available from the corresponding author on reasonable request.

\section{Compliance with ethical standards}

Conflict of interest The authors declare that they have no conflict of interest.

Open Access This article is licensed under a Creative Commons Attribution 4.0 International License, which permits use, sharing, adaptation, distribution and reproduction in any medium or format, as long as you give appropriate credit to the original author(s) and the source, provide a link to the Creative Commons licence, and indicate if changes were made. The images or other third party material in this article are included in the article's Creative Commons licence, unless indicated otherwise in a credit line to the material. If material is not included in the article's Creative Commons licence and your intended use is not permitted by statutory regulation or exceeds the permitted use, you will need to obtain permission directly from the copyright holder. To view a copy of this licence, visit http://creativecommons.org/licenses/by/4.0/.

\section{References}

1. Wu B, Li N, Ren Y (2011) $\mathrm{LiFePO}_{4}$ cathode material. INTECH Open Access Publisher

2. Padhi AK, Nanjundaswamy KS, Goodenough JBD (1997) Phospho-olivines as positive-electrode materials for rechargeable lithium batteries. J Electrochem Soc 144:1188-1194

3. Padhi AK, Nanjundaswamy KS, Masquelier C, Okada S, Goodenough JB (1997) Effect of structure on the $\mathrm{Fe} 3+/ \mathrm{Fe} 2+$ redox couple in iron phosphates. J Electrochem Soc 144:1609-1613

4. Malik R, Abdellahi A, Ceder G (2013) A Critical Review of the Li Insertion Mechanisms in LiFePO [subscript 4] Electrodes. Electrochemical Society

5. Delmas C, Maccario M, Croguennec L, Le Cras F, Weill F (2008) Lithium deintercalation in $\mathrm{LiFePO}_{4}$ nanoparticles via a domino-cascade model. Nat Mater 7:665-671. https://doi. org/10.1038/nmat2230

6. Amine K, Liu J, Belharouak I (2005) High-temperature storage and cycling of C-LiFePO4/graphite Li-ion cells. Electrochem Commun 7:669-673. https://doi.org/10.1016/j.eleco m.2005.04.018
7. Koltypin M, Aurbach D, Nazar L, Ellis B (2007) More on the performance of $\mathrm{LiFePO}_{4}$ electrodes-the effect of synthesis route, solution composition, aging, and temperature. J Power Sources 174:1241-1250. https://doi.org/10.1016/j.jpows our.2007.06.045

8. Safari M, Delacourt C (2011) Aging of a commercial graphite/LiFePO ${ }_{4}$ cell. J Electrochem Soc 158:A1123. https://doi. org/10.1149/1.3614529

9. Sun S, Guan T, Shen B, Leng K, Gao Y, Cheng X, Yin G (2017) Changes of degradation mechanisms of $\mathrm{LiFePO}_{4} /$ graphite batteries cycled at different ambient temperatures. Electrochim Acta 237:248-258. https://doi.org/10.1016/j.electacta.2017.03.158

10. Li D, Danilov DL, Gao L, Yang Y, Notten PHL (2016) Degradation mechanisms of the graphite electrode in $\mathrm{C}_{6} / \mathrm{LiFePO}_{4}$ batteries unraveled by a non-destructive approach. J Electrochem Soc 163:A3016-A3021. https://doi.org/10.1149/2.0821614jes

11. Herstedt M, Stjerndahl M, Nytén A, Gustafsson T, Rensmo H, Siegbahn H, Ravet N, Armand M, Thomas JO, Edström K (2003) Surface chemistry of carbon-treated LiFePO[sub 4] particles for Li-ion battery cathodes studied by PES. Electrochem Solid State Lett 6:A202. https://doi.org/10.1149/1.1594413

12. Edström K, Gustafsson T, Thomas JO (2004) The cathodeelectrolyte interface in the Li-ion battery. Electrochim Acta 50:397-403. https://doi.org/10.1016/j.electacta.2004.03.049

13. Hellqvist Kjell M, Malmgren S, Ciosek K, Behm M, Edström $\mathrm{K}$, Lindbergh $\mathrm{G}$ (2013) Comparing aging of graphite/LiFePO 4 cells at $22{ }^{\circ} \mathrm{C}$ and $55^{\circ} \mathrm{C}$-electrochemical and photoelectron spectroscopy studies. J Power Sources 243:290-298. https://doi. org/10.1016/j.jpowsour.2013.06.011

14. Lewerenz M, Warnecke A, Sauer DU (2017) Post-mortem analysis on $\mathrm{LiFePO}_{4} \mid \mathrm{Graphite}$ cells describing the evolution \& composition of covering layer on anode and their impact on cell performance. J Power Sources 369:122-132. https://doi. org/10.1016/j.jpowsour.2017.10.003

15. Scipioni R, Jørgensen PS, Ngo D-T, Simonsen SB, Liu Z, YakalKremski KJ, Wang H, Hjelm J, Norby P, Barnett SA, Jensen SH (2016) Electron microscopy investigations of changes in morphology and conductivity of $\mathrm{LiFePO}_{4} / \mathrm{C}$ electrodes. J Power Sources 307:259-269. https://doi.org/10.1016/j.jpowsour.2015.12.119

16. Wang J, Yang J, Tang Y, Li R, Liang G, Sham T-K, Sun X (2013) Surface aging at olivine $\mathrm{LiFePO}_{4}$ : a direct visual observation of iron dissolution and the protection role of nano-carbon coating. J Mater Chem A 1:1579-1586. https://doi.org/10.1039/ C2TA00521B

17. Koltypin M, Aurbach D, Nazar L, Ellis B (2006) On the stability of $\mathrm{LiFePO}_{4}$ olivine cathodes under various conditions (electrolyte solutions, temperatures). Electrochem Solid State Lett 10(2):A40

18. Aurbach D, Markovsky B, Salitra G, Markevich E, Talyossef Y, Koltypin M, Nazar L, Ellis B, Kovacheva D (2007) Review on electrode-electrolyte solution interactions, related to cathode materials for Li-ion batteries. J Power Sources 165:491-499. https ://doi.org/10.1016/j.jpowsour.2006.10.025

19. An SJ, Li J, Daniel C, Mohanty D, Nagpure S, Wood DL (2016) The state of understanding of the lithium-ion-battery graphite solid electrolyte interphase (SEI) and its relationship to formation cycling. Carbon 105:52-76. https://doi.org/10.1016/j.carbo n.2016.04.008

20. Ramdon S, Bhushan B, Nagpure SC (2014) In situ electrochemical studies of lithium-ion battery cathodes using atomic force microscopy. J Power Sources 249:373-384. https://doi.org/10.1016/j. jpowsour.2013.10.099

21. Steinhauer M, Stich M, Kurniawan M, Seidlhofer B-K, Trapp M, Bund A, Wagner N, Friedrich KA (2017) In situ studies of solid electrolyte interphase (SEI) formation on crystalline carbon surfaces by neutron reflectometry and atomic force microscopy. ACS 
Appl Mater Interfaces 9:35794-35801. https://doi.org/10.1021/ acsami.7b09181

22. Hiesgen R, Sörgel S, Costa R, Carlé L, Galm I, Cañas N, Pascucci B, Friedrich KA (2013) AFM as an analysis tool for high-capacity sulfur cathodes for Li-S batteries. Beilstein J Nanotechnol 4:611624. https://doi.org/10.3762/bjnano.4.68

23. Wu J, Yang S, Cai W, Bi Z, Shang G, Yao J (2017) Multi-characterization of $\mathrm{LiCoO}_{2}$ cathode films using advanced AFM-based techniques with high resolution. Sci Rep 7:11164. https://doi. org/10.1038/s41598-017-11623-0

24. Song H, Cao Z, Chen X, Lu H, Jia M, Zhang Z, Lai Y, Li J, Liu Y (2013) Capacity fade of $\mathrm{LiFePO}_{4} /$ graphite cell at elevated temperature. J Solid State Electrochem 17:599-605. https://doi. org/10.1007/s10008-012-1893-2

25. Zavalis TG, Klett M, Kjell MH, Behm M, Lindström RW, Lindbergh G (2013) Aging in lithium-ion batteries: model and experimental investigation of harvested $\mathrm{LiFePO} 4$ and mesocarbon microbead graphite electrodes. Electrochim Acta 110:335-348. https://doi.org/10.1016/j.electacta.2013.05.081

26. Simolka M, Heger J-F, Traub N, Kaess H, Friedrich KA (2020) Influence of cycling profile, depth of discharge and temperature on commercial LFP/C cell ageing: cell level analysis with ICA, DVA and OCV measurements. J Electrochem Soc 167:110502. https://doi.org/10.1149/1945-7111/ab9cd1

27. Yang F, Xie Y, Deng Y, Yuan C (2018) Predictive modeling of battery degradation and greenhouse gas emissions from U.S. state-level electric vehicle operation. Nat Commun. https://doi. org/10.1038/s41467-018-04826-0

28. Wang C, Appleby AJ, Little FE (2001) Electrochemical impedance study of initial lithium ion intercalation into graphite powders. Electrochim Acta 46:1793-1813. https://doi.org/10.1016/ S0013-4686(00)00782-9

29. Guo Z, Chen Z (2015) High-temperature capacity fading mechanism for LiFePO4/graphite soft-packed cell without Fe dissolution. J Electroanal Chem 754:148-153. https://doi.org/10.1016/j. jelechem.2015.07.009

30. Andersson AM, Edström K, Rao N, Wendsjö Å (1999) Temperature dependence of the passivation layer on graphite. J Power Sources 81-82:286-290. https://doi.org/10.1016/S0378 -7753(99)00202-5

31. Andersson AM, Edström K (2001) Chemical composition and morphology of the elevated temperature SEI on graphite. J Electrochem Soc 148:A1100-A1109. https://doi.org/10.1149/1.13977 71

32. Lu P, Li C, Schneider EW, Harris SJ (2014) Chemistry, impedance, and morphology evolution in solid electrolyte interphase films during formation in lithium ion batteries. J Phys Chem C 118:896-903. https://doi.org/10.1021/jp4111019

33. Bhattacharya S, Riahi AR, Alpas AT (2014) Thermal cycling induced capacity enhancement of graphite anodes in lithiumion cells. Carbon 67:592-606. https://doi.org/10.1016/j.carbo n.2013.10.032

34. Waldmann T, Wilka M, Kasper M, Fleischhammer M, WohlfahrtMehrens M (2014) Temperature dependent ageing mechanisms in Lithium-ion batteries - a Post-Mortem study. J Power Sources 262:129-135. https://doi.org/10.1016/j.jpowsour.2014.03.112

35. Liu L, Park J, Lin X, Sastry AM, Lu W (2014) A thermalelectrochemical model that gives spatial-dependent growth of solid electrolyte interphase in a Li-ion battery. J Power Sources 268:482-490. https://doi.org/10.1016/j.jpowsour.2014.06.050

36. Lee S-B, Pyun S-I (2002) The effect of electrolyte temperature on the passivity of solid electrolyte interphase formed on a graphite electrode. Carbon 40:2333-2339. https://doi.org/10.1016/S0008 -6223(02)00144-6

37. Anseán D, Dubarry M, Devie A, Liaw BY, García VM, Viera JC, González M (2016) Fast charging technique for high power LiFePO 4 batteries: a mechanistic analysis of aging. $\mathrm{J}$ Power Sources 321:201-209. https://doi.org/10.1016/j.jpows our.2016.04.140

38. Leroy S, Blanchard F, Dedryvère R, Martinez H, Carré B, Lemordant D, Gonbeau D (2005) Surface film formation on a graphite electrode in Li-ion batteries: AFM and XPS study. Surf Interface Anal 37:773-781. https://doi.org/10.1002/sia.2072

39. Petzl M, Danzer MA (2014) Nondestructive detection, characterization, and quantification of lithium plating in commercial lithium-ion batteries. J Power Sources 254:80-87. https://doi. org/10.1016/j.jpowsour.2013.12.060

40. Chen M, Shao L-L, Yang H-B, Ren T-Z, Du G, Yuan Z-Y (2015) Vanadium-doping of LiFePO4/carbon composite cathode materials synthesized with organophosphorus source. Electrochim Acta 167:278-286. https://doi.org/10.1016/j.electacta.2015.03.185

41. Wandt J, Freiberg A, Thomas R, Gorlin Y, Siebel A, Jung R, Gasteiger HA, Tromp M (2016) Transition metal dissolution and deposition in Li-ion batteries investigated by operando X-ray absorption spectroscopy. J Mater Chem A 4:18300-18305. https ://doi.org/10.1039/C6TA08865A

42. Talyosef Y, Markovsky B, Salitra G, Aurbach D, Kim H-J, Choi $\mathrm{S}$ (2005) The study of LiNi0.5Mn1.5O4 5-V cathodes for Li-ion batteries. J Power Sources 146:664-669. https://doi.org/10.1016/j. jpowsour.2005.03.064

43. Li D, Danilov DL, Gao L, Yang Y, Notten PHL (2016) Degradation mechanisms of $\mathrm{C} 6 / \mathrm{LiFePO} 4$ batteries: experimental analyses of cycling-induced aging. Electrochimica Acta 210:445-455. https ://doi.org/10.1016/j.electacta.2016.05.091

44. Lai Y, Cao Z, Song H, Zhang Z, Chen X, Lu H, Jia M, Li J (2012) Influence of $\mathrm{Fe}$ (II) species in electrolyte on performance of graphite anode for lithium-ion batteries. J Electrochem Soc 159:A1961-A1966. https://doi.org/10.1149/2.044212jes

45. Xiao Y, Hao D, Chen H, Gong Z, Yang Y (2013) Economical synthesis and promotion of the electrochemical performance of silicon nanowires as anode material in Li-ion batteries. ACS Appl Mater Interfaces 5:1681-1687. https://doi.org/10.1021/am302 $731 y$

46. Sun H-H, Dolocan A, Weeks JA, Rodriguez R, Heller A, Mullins CB (2019) In situ formation of a multicomponent inorganicrich SEI layer provides a fast charging and high specific energy Li-metal battery. J Mater Chem A 7:17782-17789. https://doi. org/10.1039/C9TA05063A

47. Zhu J, Zeng K, Lu L (2012) Cycling effects on surface morphology, nanomechanical and interfacial reliability of LiMn2O4 cathode in thin film lithium ion batteries. Electrochim Acta 68:52-59. https://doi.org/10.1016/j.electacta.2012.02.032

48. Ramdon S, Bhushan B (2012) High resolution morphology and electrical characterization of aged Li-ion battery cathode. J Colloid Interface Sci 380:187-191. https://doi.org/10.1016/j. jcis.2012.05.026

49. Kostecki R, Zhang X, Ross Jr. PN, Kong F, Sloop S, Kerr JB, Striebel K, Cairns E, McLarnon F (2001) Failure modes in highpower lithium-ion batteries for use inhybrid electric vehicles

50. Demirocak DE, Bhushan B (2015) Probing the aging effects on nanomechanical properties of $\mathrm{LiFePO}_{4}$ cathode in a large format prismatic cell. J Power Sources 280:256-262. https://doi. org/10.1016/j.jpowsour.2015.01.114

51. Aurbach D (1996) A comparative study of synthetic graphite and Li electrodes in electrolyte solutions based on ethylene carbonatedimethyl carbonate mixtures. J Electrochem Soc 143:3809. https ://doi.org/10.1149/1.1837300

52. Wang Y-S, Huang C-M, Hsieh H-W, Lin Y-F, Lin C-Y, Lee J-T (2014) Effect of temperature on the dissolution of solid electrolyte interface on mesocarbon microbeads electrodes in propylene carbonate-based electrolytes. Electrochim Acta 142:34-42. https ://doi.org/10.1016/j.electacta.2014.07.091 
53. Klett M, Eriksson R, Groot J, Svens P, Ciosek Högström K, Lindström RW, Berg H, Gustafson T, Lindbergh G, Edström K (2014) Non-uniform aging of cycled commercial LiFePO4// graphite cylindrical cells revealed by post-mortem analysis. $\mathrm{J}$ Power Sources 257:126-137. https://doi.org/10.1016/j.jpows our.2014.01.105

54. Hovington P, Lagacé M, Guerfi A, Bouchard P, Mauger A, Julien CM, Armand M, Zaghib K (2015) New lithium metal polymer solid state battery for an ultrahigh energy: nano C-LiFePO ${ }_{4}$ versus nano $\mathrm{Li}_{1,2} \mathrm{~V}_{3} \mathrm{O}_{8}$. Nano Lett 15:2671-2678. https://doi.org/10.1021/ acs.nanolett.5b00326
55. Lewerenz M, Marongiu A, Warnecke A, Sauer DU (2017) Differential voltage analysis as a tool for analyzing inhomogeneous aging: a case study for LiFePO4|Graphite cylindrical cells. J Power Sources 368:57-67. https://doi.org/10.1016/j.jpows our.2017.09.059

Publisher's Note Springer Nature remains neutral with regard to jurisdictional claims in published maps and institutional affiliations.

\section{Affiliations}

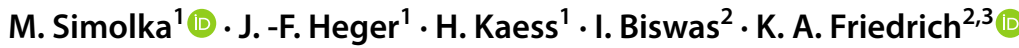

1 Faculty of Basic Sciences, University of Applied Sciences Esslingen, 73728 Esslingen, Germany

2 Institute of Engineering Thermodynamics, German Aerospace Center (DLR), Pfaffenwaldring 38-40, 70569 Stuttgart, Germany
3 Institute of Building Energetics, Thermal Engineering and Energy Storage (IGTE), University of Stuttgart, Pfaffenwaldring 31, 70569 Stuttgart, Germany 